\title{
OUTDOOR TEST CELLS FOR BUILDING ENVELOPE EXPERIMENTAL CHARACTERISATION - A LITERATURE REVIEW
}

G. Cattarin ${ }^{1, *}$, F. Causone ${ }^{1}$, A. Kindinis ${ }^{2}$, L. Pagliano ${ }^{1}$

${ }^{1}$ end-use Efficiency Research Group, Department of Energy, Politecnico di Milano, Via Lambruschini 4, 20156, Milano, Italy

2 Université Paris-Est, Institut de Recherche en Constructibilité, ESTP, F-94230, Cachan, France

*Corresponding author: giulio.cattarin@polimi.it

\section{CONTENTS}

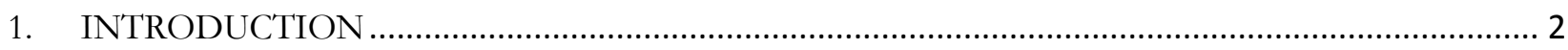

2. MAIN USES OF OUTDOOR TEST CELL FACILITIES............................................................. 4

3. MAIN CHALLENGES ENCOUNTERED IN TEST CELL DESIGN AND OPERATION ............. 5

4. CLASSIFICATION AND REVIEW OF EXISTING OUTDOOR TEST CELLS ............................. 6

4.1. TEST CELLS FOR COMPARATIVE MEASUREMENTS ................................................................... 7

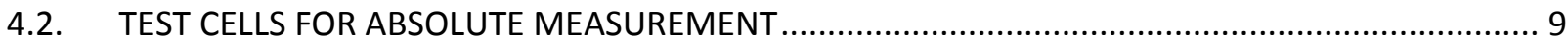

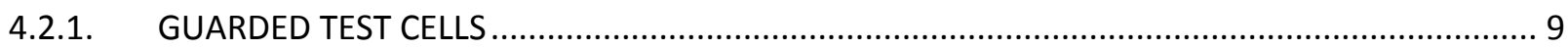

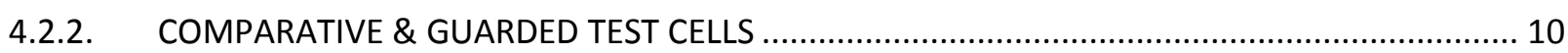

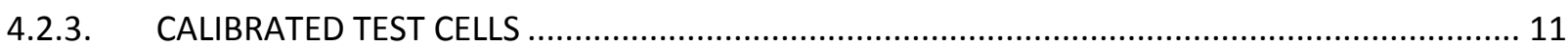

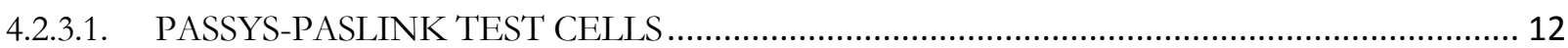

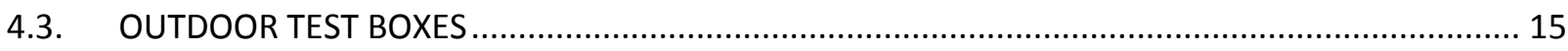

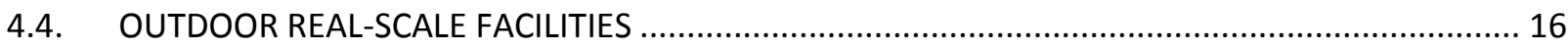

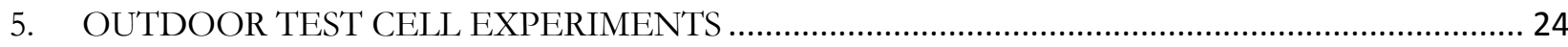

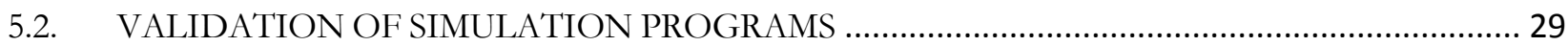

6. PERFORMANCE INDICATORS FOR GLAZED BUILDING COMPONENTS DEVELOPED BY

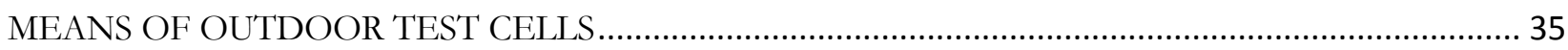

7. SYSTEM IDENTIFICATION TECHNIQUES FOR EXTRACTING PERFORMANCE

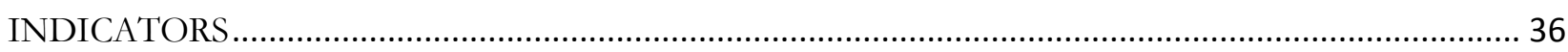

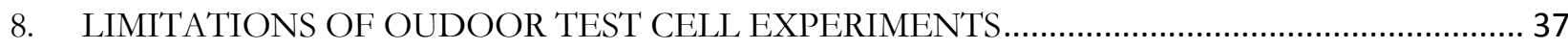

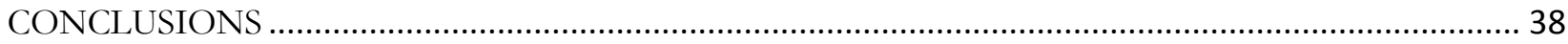

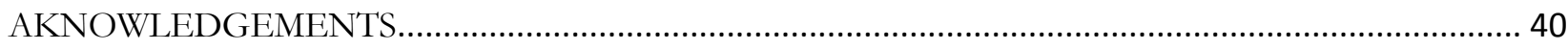

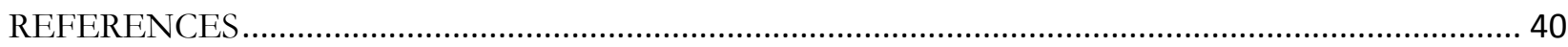




\section{ABSTRACT}

In the past decades the construction sector experienced the diffusion of a wide variety of complex building envelope components and passive elements and strategies, characterized by a dynamic response to the climatic parameters. Many of these components have been claimed to contribute to reducing building energy use and improving occupants' comfort. These kind of envelope elements need nevertheless to be tested under laboratory and real dynamic weather conditions in order to characterise, and possibly to model, their behaviour and their effectiveness both in terms of energy saving and indoor environmental quality. Both indoor laboratories and outdoor test cells have been developed in order to tackle the challenging issue of experimentally characterising innovative envelope elements. However, not always the experimental methodologies are fully and explicitly described in the available literature, and they are rarely compared to other types of experimental procedures. The aim of the present paper is to describe and review recent state of the art technologies for outdoor test cells. The paper starts with a short introduction on potentialities and limitations of outdoor facilities with respect to indoor laboratories and real buildings field tests, and it continues with a detailed classification and description of the most relevant outdoor test cells developed in recent years.

Key words: test cell, building envelope, experimental test, outdoor facility

\section{INTRODUCTION}

The market of building construction is in rapid evolution, driven by increasing requirements in terms of low-energy need and high levels of Indoor Environmental Quality ([1], [2]). Transparent components are particularly challenging, being, as remarked by Clarke et al. [3], the "weakest and strongest elements" from an energy point of view: from one side they present risks of thermal discomfort (e.g. radiant temperature asymmetry and down draughts) and visual discomfort (disability and discomfort glare), on the other side they allow the building and occupants to benefit of solar heat gains, daylight and the (hopefully pleasant) view on the outside. Also opaque building elements are undergoing a continuous optimisation process, in particular to address the market of energy efficient refurbishments. This market is increasingly asking for insulated, airtight prefabricated modules that allow to drastically reduce the installation time and the disturbance of building occupants and neighbourhood in the case of retrofit of existing buildings [4], while offering high hygrothermal performance and long durability. Highly increased airtightness in new buildings and energy efficient retrofits requires in turn the introduction of controlled ventilation, sometimes decentralised and included in envelope elements.

Façade elements thus become multi-functional, providing not only the thermal insulation of the building, but also (pre-heated) fresh air to the indoor space, the control of solar gains and incoming daylight, the control of surface condensation risk and so on. The assessment of the effectiveness by which the innovative building elements perform one or more of these functions is a complex task. Researchers and standardisation bodies are trying to identify the most appropriate procedures to correctly estimate the actual behaviour of building components in a simple and cost-effective way.

The assessment procedure may be performed by means of three main facility categories: outdoor real-scale facilities (whole buildings, possibly with occupants), laboratory indoor facilities, and 
outdoor test cells [5]. The first corresponding to in-field measurements with boundary conditions determined by weather and sometimes occupants behaviour, the second and the third to measurements under laboratory controlled boundary conditions, although in the case of test cells not all of them are under control of the research team.

It might be argued that field measurements give the most "lifelike" results, however they suffer from several constraints. First of all they are influenced both by external weather conditions and by indoor conditions, the latter depending on the characteristics of the building and the heating/cooling system and on the occupants' behaviour. It is therefore difficult to isolate a single variable, since external and internal factors simultaneously act during the measurements [6]. Secondly, obtained data may be hardly comparable with other available datasets, due to the peculiar architectural features of each real-scale building, such as surface to volume ratio, stratigraphy of walls, transparent to opaque surface ratio etc. Thirdly, it is usually difficult to obtain the high levels of instrumentation and control necessary for accurate determination of performance, due to several reasons such as the costs of the instrumentation, the presence of occupants, the characteristics of the heating/cooling system etc. [5].

Tests made in a controlled laboratory give the chance to accurately control all the most influential parameters, such as ambient temperature, relative humidity and air velocity. Examples of laboratory facilities used for testing building components are hot-box facilities for measuring thermal transmittance (in particular, with reference to standards ISO 8990:1994 [7] and ISO 12567-1:2010 [8]), spectrophotometric testing for optical properties of glazed elements, solar simulators and climatic chambers for testing the output from photovoltaic modules [9]. Laboratory experiments usually set steady-state boundary conditions, or, if at all, pre-defined test sequences. Effects of one or more outdoor weather conditions are sometimes mimicked by means of dynamic schedules (e.g. air temperature, wind speed, solar radiation or driving rain), but never fully reproducing the complex interactions of pure stochastic processes typical of real climate. Furthermore some outdoor conditions are difficult to mimic, such as radiation diffused by the sky and the ground. The control over boundary conditions on both sides of the component may be an advantage when the aim is comparing different components under very similar steady-state or cycling boundary conditions.

Test cells may fill the gap between laboratories and full-scale buildings, since they allow to keep all the necessary indoor conditions under control, while letting outdoor conditions vary as in the real environment. In particular, the interest of this type of experiments is on the interplay of external driving forces, such as external temperature, wind speed and direction, solar direct radiation, radiation diffused by the sky and the ground, external humidity and so on. Occupancy interaction (e.g. window and curtain adjustments, activation of uncontrolled internal heat sources) is excluded, and the HVAC system is fine-tuned in order to control as much as possible the indoor environmental conditions. In particular, it is fundamental to get as close as possible to the hypothesis of perfect air mixing which underpins the models commonly used for the energy balance of the test cell. 
Indoor laboratories and test cells are complementary and not antagonist facilities. Although testing under laboratory conditions offers the advantage of being replicable under close-toidentical conditions, the latter ones provide several advantages, such as the possibility to test a component under dynamic, real climatic conditions and in an indoor environment that is rather similar to an actual office space in terms of visual, acoustic and thermo-physical properties and air flow patterns [10]. In addition, test cell experiments can be used to assess the representativeness of laboratory results [11] and to empirically validate modules of building energy simulation tools [12].

Compared to field measurements in real-scale buildings, test cell experiments ensure a higher quality of instrumentation and acquisition systems, and more homogeneous indoor environmental conditions. All the most influencing variables are thus controlled, while climatic conditions are continuously monitored. In addition, the control unit allows to implement specified dynamic test sequences by controlled variations of the indoor environment (e.g. [13], [14]).

Results obtained through test cell experiments can be beneficial to many target groups, such as designers and manufacturers (to optimize the design and realisation of their products), researchers (to analyse and model the heat transfer phenomena and other physical phenomena occurring under measured boundary conditions) and end-users, who benefit from the optimised performances of products made possible by the tests [13].

The article is structured as follows. Section 2 shortly introduces the main uses of test cell facilities. Sections 3 highlights the main challenges posed to experiments, which should be carefully considered in order to obtain good results. Section 4 classifies and presents a large number of test cell facilities described in the literature, and mentions some examples of outdoor test boxes and real-scale facilities. Section 5 provides a selection of experimental campaigns on different typologies of transparent and opaque building envelope components. A selection of performance indicators proposed in order to describe the dynamic behaviour of complex building components is presented in Section 6, while Section 7 briefly recalls system identification techniques applied to test cell experiments and refers to some important works on the topic. Finally, Section 8 discusses the main technical and non-technical issues that pose boundaries to the applicability of test cell experiments.

\section{MAIN USES OF OUTDOOR TEST CELL FACILITIES}

Test cells are versatile objects that can be designed in different ways according to the type of test components that are expected to be investigated and to the main research purpose.

First of all, well-conceived test cells can be operated as calorimeters, providing accurate measurements of heat exchanges through the test cell boundary (excluding the tested envelope component), heat delivered/extracted by an active plant and hence the heat flow through the component under test (see for example ref. [10], [15] and [16]).

Another frequent approach is considering test cells simply as controlled spaces, with homogeneous indoor conditions. In this case, the test cell will just provide fixed boundary conditions to one side of the element and heat fluxes or other physical parameters of interest are 
directly measured on the component (see for example ref. [6], [17-20]). This approach is difficult to apply and may lead to misinterpretations when the component is strongly heterogeneous. In fact, each local heat flux must be weighted over an area that is considered representative, and relevant distortions of the heat flux close to the edges can hardly be measured, also considering that heat flux meters create an additional disturbance to the thermal flux. In addition, when applied to transparent elements heat flux meters need to be carefully shielded to minimize the disturbance caused by impinging solar radiation [6].

Finally, test cells can be used as office-like spaces, for tests on visual comfort, ventilation effectiveness or thermal comfort (e.g. [6], [21-28]), taking into account that test cells present certain geometric features that may not be extended to all types of offices. In the case of tests on ventilation strategies, the assumption on air temperature uniformity must be abandoned and advanced numeric tools such as Computational Fluid Dynamic may be used.

A selection of experimental campaigns conducted in test cells is presented in Section 5, which will allow the reader to gain a broad view of the potentialities of this type of facilities.

\section{MAIN CHALLENGES ENCOUNTERED IN TESTT CELL DESIGN AND OPERATION}

Test cells as every measurement equipment deliver measurements expressed as a value and an uncertainty. The overall uncertainty on estimated performance indicators depends on one side on the accuracy of the sensors and the measurement chain and on the other side on assumptions included in modelling the cell for the purpose of the analysis with respect to the actual physical behaviour of the cell, concerning inter alia:

- thermal bridges, which have a much greater relative impact on overall thermal losses compared to real buildings, due to the very large external surface area-to-volume ratio (S/V) that test cells present. Thermal bridges can occur especially at interfaces on the support wall where the test sample is installed [13].

- air infiltrations, deriving from imperfect sealing of joints. Blower door tests are usually carried out to verify whether a test cell complies with minimum airtightness requirements (maximum 0.5 air changes per hour (ach) at $50 \mathrm{~Pa}$, but also more restrictive limits have been used). Smoke tests can help identifying the most evident air leakages. In case pressurisation tests reveal air leakages over 0.5 ach, it might be necessary to continuously monitor the air leakage by tracer gas measurements [29]. In addition, maintenance is required to keep test cells tight against water penetration [30].

- unwanted oscillations of indoor air temperature, which can be smoothed by fine-tuning the control system and by increasing the thermal inertia of the test cell. Overheating problems can occur in particular in case of high solar gains through the glazed test sample.

Although real buildings generally present a non-uniform distribution of indoor air temperature, when performing test cell experiments for characterizing building elements it is in many cases necessary to guarantee homogeneous indoor climate conditions. This will allow for simplified 
assumptions in the modelling phase, such as treating the indoor air as a single node in lumped parameters models. On the other hand for certain specific measurement objectives the requirement of homogeneity is not necessary, or even not desired, e.g. when the experimental purpose is to describe the airflow patterns induced by a particular air supply system.

In addition to the challenges here described, test cell facilities present technical, economical and other limitations which restrict their field of applicability. These limitations will be summarized in Section 8, as a consequence of the analysis of test cell experiments conducted in Section 5.

\section{CLASSIFICATION AND REVIEW OF EXISTING OUT'DOOR TEST CELLS}

Within the present work, we adopt a classification method focused on the test cell construction concept and test principle adopted (comparative or absolute test), that is focusing on measurement and analysis methods rather than on output type. The intent is to provide the reader with a comprehensive understanding of the facilities, their possibilities and limitations. First of all, for sake of simplicity we separated test cells from other testing facilities, i.e. test boxes (which usually are not considered representative of real indoor spaces) and real-scale facilities (which are usually not meant for characterizing the performance of a single building envelope component). The dimensional lower threshold of test cells is here conventionally chosen as a cube of dimensions $2 \mathrm{~m} \times 2 \mathrm{mx} 2 \mathrm{~m}$ ( $\mathrm{LWWxH}$ ), below which facilities are considered test boxes. The present review focuses on test cell facilities, and includes few examples of test boxes used for building component characterisation and some examples of real-scale facilities. The authors are aware that some of the facilities may not be any more in use, but they can still offer insight on design strategies.

The review process made clear two further levels of classification of test cells according to the adopted concept (and in accordance with the ISO terminology used for Hot Box facilities [7]):

1) "Comparative test", i.e. test cells which are meant for assessing the performance of a component in relative terms, i.e. with respect to a reference element being tested at the same time (Fig. 1, left)..

2) "Absolute test", i.e. test cells which are meant for assessing the performance of a component in absolute terms by using one or more performance indices without direct contemporary comparison with another element of the same kind. And, for absolute test only, according the technology used to control/minimise heat flows through the test cell envelope:

2.a) "Guarded test cells", i.e. test cells where five of the six walls (the sixth being the place where the component is located) are not directly exposed to outdoor weather conditions, but are surrounded by a thermally-controlled (guard) zone(i.e. a conditioned buffering zone with the aim to reduce heat loss/gains through five of the six walls, visible in Fig. 1, centre). 
2.b) "Calibrated test cells", i.e. test cells that reduce the conduction heat exchanges through five of the six walls by means of a thick layer of insulating material (Fig. 1, right). The test cell is calibrated by measuring the power flow through these walls for a range of operating conditions, using the calibration panels. Most of these cells are directly exposed to external weather conditions. PASSYS-PASLINK test cells have been included here for their design concept, even though at several test sites two or more cells have allowed also comparative tests to be performed.

A few facilities belong both to the "comparative" and to the "guarded" families, and will be thus presented in a dedicated section.

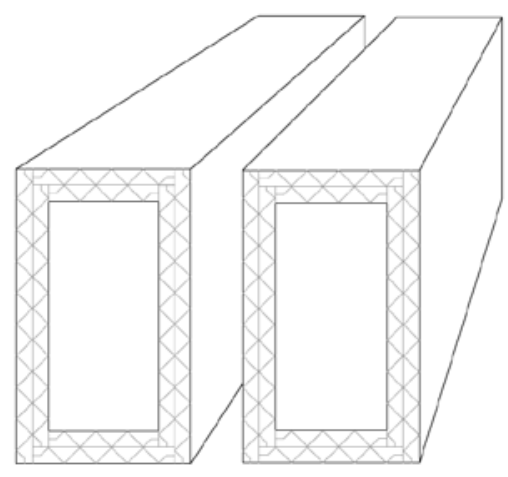

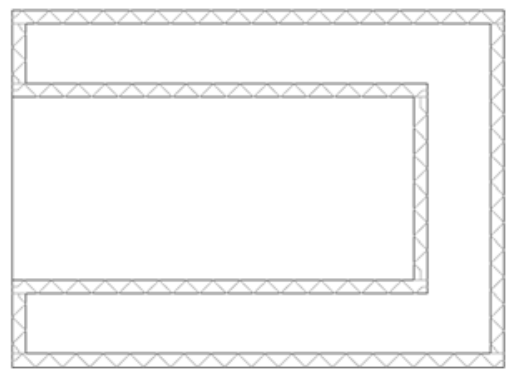

GUARDED TEST CELL

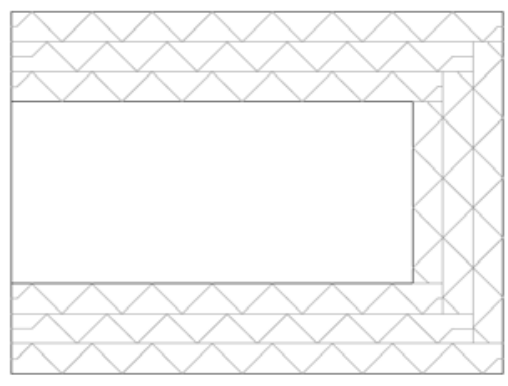

CALIBRATED TEST CELL

\section{COMPARATIVE TEST CELLS}

Figure 1. Schematic representation of test cells, according to the classification proposed by the authors. On the left: a perspective view of comparative test cells; in the centre: a vertical section of a guarded test cell; on the right: a vertical section of a calibrated test cell.

\subsection{TEST CELLS FOR COMPARATIVE MEASUREMENTS}

Comparative test cells allow to assess the relative performance of a certain building envelope component with respect to a reference element as described e.g. in Serra et al.[6]. Given $n$ test components to be tested and a reference component $R$, a series of experiments will be performed exposing the $\mathrm{i}$-th test component and $\mathrm{R}$ at the same time to the external weather conditions. This simplifies the interpretation of results, in particular when the reference element is a conventional, well-known product [31]. As explained in [6] «the use of a reference test cell allows comparisons to be made between various configurations and sensitivity analyses to be developed, varying different façade features, even though the boundary conditions are not exactly the same during the various tests». The following paragraphs illustrate some examples of comparative test cells, highlighting specificities of the heating/cooling system, the monitoring equipment and the type of tests performed.

The solution implemented by Politecnico di Torino consists of two identical test cells mounted on a roof and fully exposed to solar radiation [6]. One cell is used as a reference, while on the other cell the test components can be installed, such as active transparent façades. A full-air system keeps the indoor air temperature within a range of $\pm 1^{\circ} \mathrm{C}$ of a chosen set-point. The physical 
parameters that can be measured include: air temperature, glass and frame surface temperatures, incident and transmitted irradiance, heat fluxes, mechanically driven air flow rate and pressure difference [32].

The Energy Monitoring Company (EMC) test rooms described by Lomas et al. [33] reproduce typical lightweight rooms in UK houses in terms of insulation levels, thermal mass and window-tofloor area ratio. The rooms are built in pairs, separated by a heavily insulated partition wall. The outer walls are of stud-frame construction covered by plasterboard, and they have concrete slabs on the floor. Air changes per hour due to infiltration were reduced to less than $0.05 \mathrm{~h}^{-1}$ thanks to optimal sealing.

The Building Science -Research \& Test Unit (Carinthia University of Applied Sciences, Austria) allows to test roofs and walls of different width (single separators can be displaced), exposed to south or north [14]. The western façade is used for studies regarding wind-driven rain impact. The test facility is equipped with a double air conditioning system, one for the main room (range: $\mathrm{T}_{\text {air }}: 20 \div 24^{\circ} \mathrm{C}, \mathrm{RH}: 30 \div 50 \%$ ) and one for the smaller space at the western façade, where translucent building materials such as membrane structures can be tested. This allows to conduct separate tests in the two rooms without mutual influences.

A set of eight test cells in Algete, near Madrid, is described by Revel et al. [34]. Each unit has dimensions of $2.4 \mathrm{~m} \times 3.0 \mathrm{~m} \times 2.4 \mathrm{~m}(\mathrm{LxWxH})$ with walls and low-slope roof composed by an internal plasterboard layer $(1.2 \mathrm{~cm})$, an air gap $(7.5 \mathrm{~cm})$ and an external Oriented Strand Board layer $(2.5 \mathrm{~cm})$. The panels are anchored to an internal steel frame structure erected on a monolithic concrete slab $(10 \mathrm{~cm})$ that lies on four concrete blocks to reduce the heat transfer with the ground. The test cells present a PVC door on the north and two windows on the east and south façades. A fan controlled by a speed regulator can be installed on the northern façade. Differently from most facilities, the cells in Algete Demo Park operate in free-floating conditions, simulating unconditioned indoor spaces.

The nine house-like cubicles in Puigverd de Leida (Spain) described by Cabeza et al. [35] are simple structures made of four mortar pillars with reinforcing bars and a concrete base. They are conceived to host walls of different configurations (various types of bricks and insulation materials), while a reference cubicle with no insulation provides a performance benchmark. The cubicles can operate both in free-floating and in controlled mode; in the latter case an air conditioner and an electrical oil radiator keep the internal temperature set-point.

The comparative test facility in Alveiro (PT) present external dimensions $7 \mathrm{~m} \times 2.35 \mathrm{~m} \times 2.58 \mathrm{~m}$ and a transparent façade south-oriented, where test samples can be installed [36-37]. The cell structure consists of galvanized steel profiles supporting $4 \mathrm{~cm}$ thick sandwich panels with polyurethane foam, while the roof is composed by sandwich panels including $8 \mathrm{~cm}$ of fibre glass with water vapour barrier. An internal partition splits the facility in two identical compartments.

Located in Malaysia on the roof of a seven-storey building, the test cells described by Qahtan et al. [38] present a steel structure bearing sandwich panels with $10 \mathrm{~cm}$ insulation, an external metallic 
sheet and an internal plywood board. They have internal dimensions $2 \mathrm{~m} \times 2 \times 2.6 \mathrm{~m}$ and a removable wall facing west.

Two test facilities were built for the experiment conducted by Young et al. [39] in Taipei. Two units of heat insulation solar glass (HISG) were installed on both the south-facing roof and vertical windows of one of the houses, hence called HISG House, and two units of single-layer tempered glass 10-mm thick were installed on the same locations on the other house (Ordinary House). The stratigraphy of the walls consisted in two boards of cement and calcium silicate separated by a $65 \mathrm{~mm}$ air gap, a $25 \mathrm{~mm}$ XPS board and a cement mortar coating, resulting in an overall U-value of about $0.3 \mathrm{~W} \mathrm{~m}^{2} \mathrm{~K}^{-1}$.

\subsection{TEST CELLS FOR ABSOLUTE MEASUREMENT}

Tests made in these facilities allow to characterize the performance of building components on the basis of some monitored boundary conditions, adopting common or ad-hoc defined performance indices and without any comparison against a reference. Two major construction concepts have been identified to minimize heat loss/gains through the envelope: guarded and calibrated test cell.

\subsubsection{GUARDED TEST CELLS}

These facilities present an internal test room that is surrounded on five sides by a thermallycontrolled (guard) zone. By minimizing the air temperature difference between the guard zone and the test room, energy flows through the sixth, outdoor facing wall, (where the component under test is installed) become far greater than the flows through the remaining faces, thus allowing for a more accurate determination of the heat losses through the component under test [40]. Guarded test cells guarantee a high control of boundary conditions, provided that the air in the guard zone is well mixed and that the two independent HVAC units for the test cell and the guard zone are adequately sized and controlled.

The most accurate description of a guarded test cell is given by Manz et al. [40]. The Material Testing and Research (EMPA, Switzerland) facility consists of two identical test cells where all interior construction elements are adjacent to a temperature-controlled guard zone for better control of boundary conditions ([41], [42]). Conditioned air is supplied through two textile ducts at the floor level, while exhausts are located at the ceiling level, thus creating a flow pattern close to a piston flow [40]. The external chamber is covered with aluminium foils that reflect solar radiation, while a uniform ground reflectance is ensured by means of a green artificial turf installed in front of the test cell [43].

The Cube in Aalborg (DK) consists of four domains, which are named as: double-skin façade (DSF), experiment room, instrument room and plant room. The test cell has been conceived to test double-skin facades with natural and mechanical ventilation and different shading systems. The temperature in the experiment room can be kept constant by means of a cooling unit installed in the plant room and a ventilation system with the heating and cooling unit installed in the experiment room [44]. In order to avoid temperature gradients in the experiment room, a 
recirculating piston flow with an air speed of approximately $0.2 \mathrm{~m} \mathrm{~s}^{-1}$ is used. This resulted in typical temperature gradients of maximum of $0.1^{\circ} \mathrm{C}$ per meter height. The air intake for recirculation is at the top of the room, after the intake the air passes through the preconditioning units of the ventilation system and then it is exhausted at the bottom of the room through the fabric KE-Low Impulse ${ }^{\circledR}$ ducts. It should be noted that the ducts affect the absorption of solar radiation on the floor surface [44]. The maximum power for the cooling and heating unit are 10 $\mathrm{kW}$ and $2 \mathrm{~kW}$, respectively. A large carpet was fixed on the ground facing the southern facade of the cell to achieve uniform reflection from the ground [45]. The size of the carpet ensured a view factor between the double-skin façade and the ground of about 0.5 . The carpet has a reflectance of 0.1 (standard value for asphalt), and is permeable to water to maintain its reflectance value approximately constant even in wet conditions. The MINIBAT test facility in Cethil (FR) consists of two identical cells. One face of one of the rooms is adjacent to a climatic chamber, which can simulate outdoor weather conditions in terms of air temperature and solar radiation while all the remaining sides are thermally guarded [46]. This facility is thus closer to a laboratory than to an outdoor test bed. However, it is interesting to point out that it allows to study heat and air transfers within one room, or between two rooms, or through an external wall coupled with one of the rooms. At our best knowledge, it is the only test facility that currently allows to directly couple two rooms, although a previous concept of double test facility was reported in 1995 by Kalema and Haapala [47].

\subsubsection{COMPARATIVE \& GUARDED TEST CELLS}

A few hybrid cases of comparative-guarded test cells include the BESTLab (Building Envelope and Solar Technologies Laboratory) and the ETNA (Essais Thermique en climat Naturel et Artificiel) facilities. The former, built in 2010 on the EDF site of the Renardières (about $75 \mathrm{~km}$ southeast of Paris) [48], hosts twelve independent cells distributed on two floors, the upper ones enabling tests on roof components. On each level there are four cells south-oriented, one exposed to east and one to west. The walls present a very low $\mathrm{U}$-value $\left(\mathrm{U}<0.1 \mathrm{Wm}^{-2} \mathrm{~K}^{-1}\right)$ and are kept at constant temperature being surrounded by a thermally controlled zone. For the purpose of the experiments, an air handling unit has been built inside one of the cells: heating is provided by an electrical resistance while a cooling coil provides the cooling power.

The test cell laboratory named ETNA [48] contains two identically designed and oriented test cells separated and surrounded by individually-adjustable guard zones. On the southern wall a mobile thermally guarded zone can be installed in order to create artificial boundary conditions. Both cells present intake ducts located near the ceiling, and four supply-air diffusers near the floor oriented as the test cell length axis. The air distribution fan and the heater are contained within the ductwork, where heating electric power, fan electric power, and fan airflow rate can be continuously monitored. According to Neymark et al. [49] a Proportional-Integral-Derivative (PID) thermostat controller ensures that the air temperature can be kept within a very narrow range of $\pm 0,1^{\circ} \mathrm{C}$.

A third example is offered by the Mobile Window Thermal Test (MoWiTT) Facility (USA), consisting of two calorimeters surrounded by a guard zone and mounted on a mobile structure [50]. The 
heating/cooling system consists of an electric heater, a liquid to air heat exchanger with measured heat flow rate and inlet/outlet temperatures, and a nearly continuous interior skin of large area heat flow sensors. There are also provisions for measuring all auxiliary electric power dissipated inside the chambers (e.g. fan power). The facility has been used to test electrochromic skylights ([51], [52]).

Xu et al. [53] conducted an experimental campaign in a test cell built on the roof of a building in Wuhan, China. The experimental room contains two inner chambers sharing a guard room, each presenting a window on the southern façade.

\subsubsection{CALIBRATED TEST CELLS}

These facilities rely on high levels of thermal insulation to reduce heat loss/gain through the cell envelope and they aim at characterizing the component performance in absolute terms. These cells greatly differ in terms of dimensions, conditioning system and type of tests performed.

The VLIET Test building (K.U.Leuven, Belgium) presents test walls in the longitudinal façades, facing southwest, and northeast, in order to test the hygrothermal behaviour of components respectively in conditions of solar irradiation and wind pressure and in conditions of shade and under-pressure [14]. The test building is divided into two modules, separately controlled by the HVAC-system. The thermal performance of sloped roofs can be tested in one of the modules [54], while a small additional test room at the southwest side can be used for the applications of passive solar energy, solar shading devices, etc. The facility allows the simultaneous testing of 20 wall systems, 4 flat roofs and 6 duo-pitched roof systems exposed to the cool and humid West-European climate. In addition to ordinary outdoor weather sensors, rainwater gauges are installed in the free field in front of the building and at several points of the building façade in order to study the impact of driving rain (i.e. rain carried by the wind and driven onto the building envelope) on buildings.

The Jacques Geelen Laboratory (Université De Liège, Belgium) includes four zones: the climate chamber, surrounded by a buffer space ( $1 \mathrm{~m}$ width) to better control the chamber temperature, the offices zone and the technical area [14]. The boundary conditions can be imposed either by the natural climate (when the whole building is used as test object) or by the buffer space in which an artificial climate can be created (when the experiment focuses on the climate chamber). In the latter case - which applies the "guarded" concept - the range of air temperature is between $5^{\circ} \mathrm{C}$ and $40^{\circ} \mathrm{C}$, and hourly or sub-hourly sequences can be imposed.

The Fraunhofer Institute for Building Physics at Holzkirchen has recently developed a calorimetric test facility for façades and roofs that can be turned by $360^{\circ}$ and tilted by $90^{\circ}$ in order to have full control on the orientation of the analysed component [14]. The facility can be moved heliostatically, to expose the specimen to normal radiation at all time, or it can track the sun according to predefined control logics. It is thus possible to characterize the solar heat gain coefficient for different solar incidence angles. At the same test site, a modular three-storey construction in reinforced concrete can host, on each floor, six square test cells, which can be 
investigated both individually and in combination. The false ceilings are partially demountable in order to recreate bigger indoor spaces, while removable roof slabs allow integrating transparent roof components [14].

The test facilities used by Guychard et al. [55], Mara et al. [56] and Miranville et al. [57], have been set up at the south of Reunion Island (FR), at a low altitude from the sea level. The location was chosen to address the specific challenges posed by a tropical climate with strong solar radiation and humidity. This platform is composed of different test cells, some of them being lowscale devices (called ISOTEST) and a normal scale building (called LGI). The LGI test cell reproduces a typical room of a building, with an interior volume of about $30 \mathrm{~m}^{3}$. It is designed with a modular structure (movable walls) in order to test several configurations [57]. The cell is equipped with mechanical ventilation and split-system air conditioning. The cell has been used to test phase change materials (PCM) embedded in the roof [55], a radiant barrier system [57] and to validate an empirical thermal model [56].

Two small test facilities were constructed in Portugal. The first, located in a mountain region in central Portugal and briefly described by Carlos et al. [17], was used to characterize two double window systems under winter conditions. The second, described by Mateus et al [58], presents a southeast-facing double skin ventilated facade (DSF) that is divided into two adjacent volumes. It has an aerated concrete based construction, and a concrete floor in contact with the ground. $A$ ceiling exhaust fan drives an airflow of $2.5 \mathrm{~h}^{-1}$, while the inflow is guaranteed by a grille in the door that leads to the lateral access corridor.

A test cell at Delft University (NL) was used by Stec and van Paassen [59] to measure the thermal performance of a double skin façade, for different settings of the façade and the internal system. Several sorts of glass could be applied as well as different ventilation openings, positions of the valves in the cavity, blinds and windows. The results of the experiments were compared with those obtained using a laboratory test facility and an office in a real building equipped with double skin façade.

A separate section follows, dedicated to the PASSYS-PASLINK project test cells for their relevance, broad diffusion and scientific contribution to the topic of test facilities.

\subsubsection{PASSYS-PASLINK TEST CELLS}

One of the largest harmonized test cell experimentation started in 1986 with the European Community's Passive Solar Components and Systems Testing Project (PASSYS). Under this programme (1986-1989 PASSYS I, 1989-1993 PASSYS II), 35 test cells were constructed in 10 countries across Europe, enabling the derivation of objective data under a wide variety of climatic conditions [60]. The network consisted of about sixty researchers, and the activities addressed test methodology, validation and development of simulation models, development of simplified design tools, definition of instrumentation and passive solar components ([13], [61]).

A PASSYS test cell is a two-rooms prefabricated facility, where the larger room, called "Test room", has a removable wall aperture where test samples can be installed. Good mixing of indoor air is achieved by means of two textile hoses inclined from the ceiling to the floor, which supply air at small velocity and in a uniform manner. In addition, a fan running at constant speed circulates the 
air to avoid any remaining air temperature stratification. The smaller room, called "Service room", serves as space for control and measuring equipment, and in some cases hosts a small heating unit to keep its own indoor temperature at the desired value. The test room and the service room are divided by a well-insulated partition containing a sealed connecting door [13]. Both indoor and outdoor conditions are monitored by standard sets of sensors which allow to measure solar radiation (diffuse and direct), long wave radiation, wind speed and direction, relative humidity, air temperatures, envelope and component surface temperatures, heat fluxes and heating and cooling power ([62], [63]). The test room can be installed on a rotational platform, allowing tests to be performed under different orientations. One of the aims of PASSYS was to enable cross comparison of experiments performed in different climate zones (ranging from Mediterranean to Scandinavian countries) so to check whether the same component performance indicators can be derived (up to a certain level of accuracy) irrespective of climate [5].

In 1994 the PASLINK Network evolved from PASSYS Network to improve the evaluation techniques for the assessment of the thermal performance properties of passive solar components. In particular, PASLINK developed agreed quality procedures for testing, which include calibration methods for the instrumentation and the test cell, dynamic techniques for data processing and analysis and simulation methods for scaling and replication ([64], [65]). Three different technologies were developed within PASLINK Network. An active layer, called pseudo-adiabatic shell (PAS), was developed by Belgian Building Research Institute (BBRI) and added to the test cell envelope, with the three aims of a) reducing the response time of the facility, b) minimizing the heat losses through the test cell envelope and c) measuring the temperature difference across the test cell envelope on a dense grid [66]. The PAS consists of an electric heating foil and a sequence of insulating and conductive materials on the interior side. The mean temperature difference between two aluminium plates (located at both sides of an internal insulation layer) is measured by thermopiles. The thermopile signal is used to control the heating foil in such a way that the resulting heat flux comes close to zero. In the case of a higher temperature of the internal aluminium plate the power of the heating foil is switched on ([67], [68]). In essence, this system detects heat fluxes through the test cell envelope by means of thermopiles, and compensates the heat losses by means of a heating foil device [14].

An alternative technical improvement was suggested by TNO Building and Construction Research (Netherlands), consisting of the so-called "Heat Flux Sensitive tiles". Compared to the PAS system, the advantage is that the thickness of the elements is only a few millimetres. As reported in Hahne \& Pfluger [67]: «The idea of the tile installation is to set up a grid of heat flux sensors in order to better approximate the total heat flux passing through the test cell envelope. A disadvantage is, however, that the tiles are costly both in manufacturing and installation ".

About 240 tiles are necessary to cover the test cell inside walls and they need to be calibrated in situ prior to the tests, to check for edge effects, thermal bridges and other irregularities in the signals ([15], [69]). Further information on the HFS Tiles is provided in Van Der Linden et al. [70]. According to Erkoreka et al. [15], the method of HFS Tiles simplifies operation, calibration and maintenance of the cell compared to the PAS method. It is however important to consider that the solar radiation impinging on the floor of the cell through a transparent element under test will 
affect the HFS Tiles signal, complicating the model that describes the heat flux phenomena [15]. A simple way to avoid short wave radiation directly on the HFS Tiles is to use a black curtain, which absorbs the solar radiation and transfers the heat via convection and long wave radiation to the test room preventing direct solar radiation hitting the tiles [15]. The test site inspections carried out in 2001-2003 within IQ-TEST project, report 12 and 18 cells respectively equipped with a PAS and a HFS Tiles system [30].

The third improvement developed by TNO and ITW is a movable cold box for obtaining steady-state conditions (or better, "partly artificial boundary conditions", as expressed in [70]) in front of the test component. This cold box can temporarily be placed outside, in front of the test façade, in order to obtain specific conditions (low temperature, constant wind speed, absence of solar radiation). Both open (no control on air temperature) and closed cold boxes (full control of outdoor boundary conditions) can be mounted. The main requirement for the closed cold box is to create steady-state conditions (e.g. temperatures between -10 and $40^{\circ} \mathrm{C}$ and constant wind speed at $4 \mathrm{~m} / \mathrm{s}$ ) for at least two weeks. The cold box can be used for different test cells and can be removed to conduct dynamic tests with solar radiation [67]. In order to facilitate the moving of the device (weighing more than 2 tons), a special rail system can be constructed [71].

These improvements helped reducing the test duration for the thermo-physical characterisation of building envelopes, from eight weeks down to one or to two weeks, thus reducing drastically the operation and staff costs for experiments. Guidelines for the installation and use of the PAS and the HFS Tiles systems as well as for the data analysis were developed within COMPASS project (see ref. [68], [69] and [72]).

An important remark is that PASSYS test cells have been initially used either as stand-alone facilities or following a comparative approach, but the innovations introduced in PASLINK moved the experimental methodology towards absolute tests. For this reason they are here classified as calibrated test cells.

In recent years, the scientific staff of the Laboratory for the Quality Control in Buildings (LCCE) of the Basque Government developed an insulated frame in order to test flat (or slightly pitched) roof samples as accurately as vertical walls, by minimizing border effects [73].

The work of PASLINK Network was continued within IQ-TEST (Improving Quality in Test and Evaluation procedures of Solar and Thermal performances of building components) Thematic Network (started in 2000), which developed quality procedures for testing, calibration, data processing, scaling and maintenance of the test infrastructures at the test sites [29]. One of the activities consisted of round-robin tests, with the aim of developing standards for outdoor testing [74]. Each partner constructed its own components according to common criteria of selection of materials, manufacture and instrumentation.

In addition, the accompanying measure project DAME-BC (Dynamic Analysis and Modelling applied to Energy performance assessment and prediction of Buildings and Components), started in 2002, created a platform for the exchange of the expertise on outdoor testing and dynamic analysis and to provide training on advanced software tools such as LORD and CTSM. The PASLINK EEIG network has changed its legal position in 2009 and has become an integrated network under 
INIVE EEIG, with the creation of the platform DYNASTEE (Dynamic Analysis, Simulation and Testing applied to the Energy and Environmental Performance of Buildings) [75].

The most recent test cell built according to PASLINK concept has been finalized in 2013 in Florence, at the TAD Department of Technology for Architecture and Design "Pierluigi Spadolini" [14]. The cell is laid on a rotating platform allowing different orientations and, differently from previous PASLINK cells, it is entirely realized in wooden structure to minimize thermal bridges [76]. In addition, the envelope is covered by an external shading to avoid the direct solar radiation. The screening is a grid realized in wood material at a distance of $20 \mathrm{~cm}$ from the test cell envelope to guarantee an adequate ventilation of the air cavity.

\subsection{OUTDOOR TEST BOXES}

In the present review we have indicated as "test boxes" those facilities that have an internal volume below $8 \mathrm{~m}^{3}$, corresponding to internal dimensions of $2 \mathrm{~m} \times 2 \mathrm{~m} \times 2 \mathrm{~m}$ ( $\mathrm{LxWxH}$ ). This section presents a few examples of test boxes used for building component characterisation.

The device described in Lopez et al. [77] consists of a cubic box with an interior edge of $0.6 \mathrm{~m}$ and one open side. The stratigraphy of the test box from the inside to the outside is: $12 \mathrm{~mm}$ thick plywood with anti-damp treatment, $160 \mathrm{~mm}$ thick extruded polystyrene and $4 \mathrm{~mm}$ thick reflective insulation comprising a $8 \mu \mathrm{m}$ pure aluminium sheet and a $4 \mathrm{~mm}$ layer of polyethylene bubbles. The overall thermal transmittance was estimated about $0.18 \mathrm{Wm}^{2} \mathrm{~K}^{-1}$. The test box was used to investigate the thermal behaviour of a double glazing with a circulating water chamber.

The test boxes in Madrid described by Olivieri et al. [31] are made of $160 \mathrm{~mm}$ thick extruded polystyrene (XPS) board with phenolic plywood in both sides and a protective plastic film as outer layer. The overall thermal transmittance is about $0.2 \mathrm{~W} \mathrm{~m}^{2} \mathrm{~K}^{-1}$. The facility was used to test the thermal, daylighting and electrical performance of semi-transparent photovoltaic modules and compare it with a code-compliant conventional glass.

The experimental testing facility at Hong Kong Polytechnic University is composed of two identical test cells, each with the dimensions of $1.22 \mathrm{~m} \times 0.82 \mathrm{mx} 0.99 \mathrm{~m}$. The cells were used to study the fluid flow in the air cavity and thermal performance of a double sided façade with transparent thin-film or a-Si solar cells [78].

Piccolo [79] employed a small cubic test box (interior edge of $43 \mathrm{~cm}$ ) to study the thermal and optical properties of a small-size double glazing unit where the outer pane has an electrochromic behaviour. The thermal transmittances of the front-wall and of a side wall of the test box were estimated to be respectively 2.4 and $1.2 \mathrm{Wm}^{2} \mathrm{~K}^{-1}$.

A study by Ahmad et al. [80] explores the thermal performance of building components incorporating a phase change material coupled with a vacuum insulation panel (VIP). The two test boxes constructed consisted of one glazed face and five opaque faces insulated with VIPs and placed on a frame made of white PVC profiles. One of the cells is equipped with five panels containing PCM, while the other is kept as reference (following a comparative test approach). 
The Test Reference Environment of Lleida (TRE-L) prototype described by Lodi et al. [81] is composed by a thermally well insulated wooden box (with external dimensions of

$2.06 \mathrm{~m} \times 2.36 \mathrm{~m} \times 0.37 \mathrm{~m}$ ) and a support structure which allows to incline the device. The walls of the box are sandwich panels formed by $0.02 \mathrm{~m}$ thick plywood layers filled with a $0.2 \mathrm{~m}$ thick expanded polystyrene (EPS) and painted with white varnish to minimize solar absorption. The prototype has a south facing opening where a glass-Tedlar ${ }^{\circledR}$ monocrystalline-Si PV module (dimensions:

$0.98 \mathrm{~m} \times 1.51 \mathrm{~m}$ ) is positioned.

A round robin test box experiment started in 2013 within IEA ECBCS Annex 58 "Reliable Building Energy Performance Characterisation Based on Full Scale Dynamic Measurements" [82]. The test box has been sent around to different institutes to be monitored under different climatic conditions. In addition, obtained dynamic data sets were sent to different institutes to characterise the test box. The aims of this experiment were to investigate the reliability of full scale testing and dynamic data analysis, understand the influence of climatic conditions on characterisation, provide well-documented data set for validation and thus determining the state-of-the-art and the next steps to do towards more complex (real) buildings.

\subsection{OUTDOOR REAL-SCALE FACILITIES}

Real-scale facilities comprehend a large variety of prototype buildings that present high levels of hygrothermal performance and the possibility to monitor energy consumption and indoor climate conditions in presence of occupants. A thorough review of real-scale facilities would require a dedicated publication, however a few examples may provide a glimpse of the potentialities of these facilities both for scientific research and for product innovation. Experiments carried out in real-scale facilities usually aim at evaluating the overall energy performance of the building, often in combination with occupancy interaction.

One of the most recent demonstration park is FLEXLAB (the Facility for Low Energy EXperiments in Buildings) located in LBNL, Berkeley (USA) [83]. A number of test facilities with different purposes has been constructed, such as four testbeds with same orientation and a fifth presenting two 2story spaces, allowing to investigate thermal convection or high bay lighting. In addition, it will be possible to conduct studies on occupancy behaviour in the Lighting/Plug Load Testbed, located on the 4th floor of an existing building, where each light fixture and each electrical outlet can be separately metered and controlled [14].

The EnergyFlexHouse ${ }^{\circledR}$ in Taastrup (DK) consists of two 2-story single family houses, one of which is used as a laboratory (EnergyFlexLab), while the other (EnergyFlexFamily) is occupied by families for three to five months at a time [84]. The former can be used for several purposes, such as testing the coupling with a low temperature district heating [85], the storage capacity of phase change materials in the floor slab, the performance of high-efficient windows and demand controlled ventilation, the in-situ production from renewable energy sources etc. The research on the occupied house is instead focused on the actual energy consumptions throughout the year, the user acceptance of different energy efficient lighting systems, the optimized control of the installation guaranteeing proper indoor climate conditions etc. [14]. 
Local climate conditions play a key role both on design choices and on occupants' behaviour. A single-family zero energy building located in the municipality of Mascalucia (Catania, Italy) will soon be monitored in Mediterranean climate under real occupancy conditions [86]. The building relies in summer on passive cooling strategies (night ventilation, air to earth heat exchanger coupled to the mechanical ventilation system) and produces locally renewable energy by means of photovoltaic modules and a thermal solar system ([86-88]). The building automatic control system allows to monitor and evaluate different strategies for the adjustment of solar protection and mechanical ventilation, considering the dynamic effects of heat storage in building components. Thermal comfort parameters and electricity consumption of fans and other equipment will be continuously measured.

The two Test-Rooms built in 2012 at the Engineering School of University of Perugia (Italy) represent typical Italian construction practice in terms of materials, geometry and HVAC technologies [89]. The walls of the two facilities present the same thermal transmittance but a different heat capacity, which allows to investigate the effect of thermal storage on the dynamics of the buildings. So far, the main focus is on the hygrothermal behaviour during the winter season, performed by means of detailed monitoring of the energy consumptions and the indoor and outdoor conditions.

The INCAS platform (Le Bourget du Lac Cedex, FR), developed since 2008, includes four PASSYS test cells, four experimental houses and ten PV-integration benches. The four, unoccupied houses present the same external and internal geometry, but differ in the building materials used. They are meant to test different insulation strategies, ventilation systems, solar thermal heating and domestic hot water systems. The facilities have also been used by Gouy-Pailler et al. [90] to investigate distance and similarity measures that simplify data interpretations for energy management purposes.

Numerous other real-scale facilities are described in Janssens et al. [14], such as the PSE ARFRISOL C-Ddls Energy Research Demonstrator Office Building Prototypes (ES) [91], the NRC-IRC's Field Exposure of Walls Facility in Ottawa (CA) or the outdoor testing site in Holzkirchen (DE), the latter comprising 27 test-houses and seven office and laboratory buildings.

\subsection{COMPARISON OF THE VARIOUS TEST CELL CONCEPTS}

The tree diagrams in Figure 2 present a comprehensive classification of outdoor test facilities, including some examples of test boxes and real-scale buildings. An overlapping region between comparative and guarded cells includes four of the presented cases. We remark again that PASSYS-PASLINK test cells have often been built in pairs in order to perform also comparative tests, but their design concept actually aims to absolute test procedures.

Comparative test cells allow to assess the relative performance of a certain building envelope component with respect to a reference element [6]. However, when the individual test cells are not well insulated and controlled, it may not be possible to assess the performance of the component in absolute terms. In other words, the assessment will strictly depend on the reference 
element, which depend on the choices of the single researcher or the research team but it is not standardized or internationally agreed (e.g. single clear glazing $3 \mathrm{~mm}$, double glazing, etc.) Guarded test cells guarantee the best control of boundary conditions, providing that the air in the guard zone (sometimes called buffer) is well mixed and that the single HVAC units for the test cell and the guard zone work properly (for example, a study by Manz et al. [42] reports vertical air temperature stratifications of up to $4 \mathrm{~K}$ in the guard room). However, limitations may be posed by economic constraints, since qualitative considerations (based on construction dimensions and redundancy of materials) suggest that guarded test cells need a much more massive construction, a greater design effort and higher maintenance and operation costs. Economic assessment on the costs of test cell design and construction are not publicly available at present, so more precise comparisons are still not possible.

A final, important remark is that in a number of cases the available scientific literature misses to deliver substantial information on the test cell characteristics and operation (e.g. internal dimensions, stratigraphy of the walls, heating/cooling system) and on the local climate conditions, thus undermining the replicability and the interpretation of the performed tests.

Table 1 summarizes the main aspects of the test cells presented so far, with indications on the dimensions, the building materials, the types of tests performed and the main strengths of each test facility.

This review addressed all of the test cell typologies available in the literature; however, some single facility might not have been included because still under development or because of the limited space allowed to the review. 


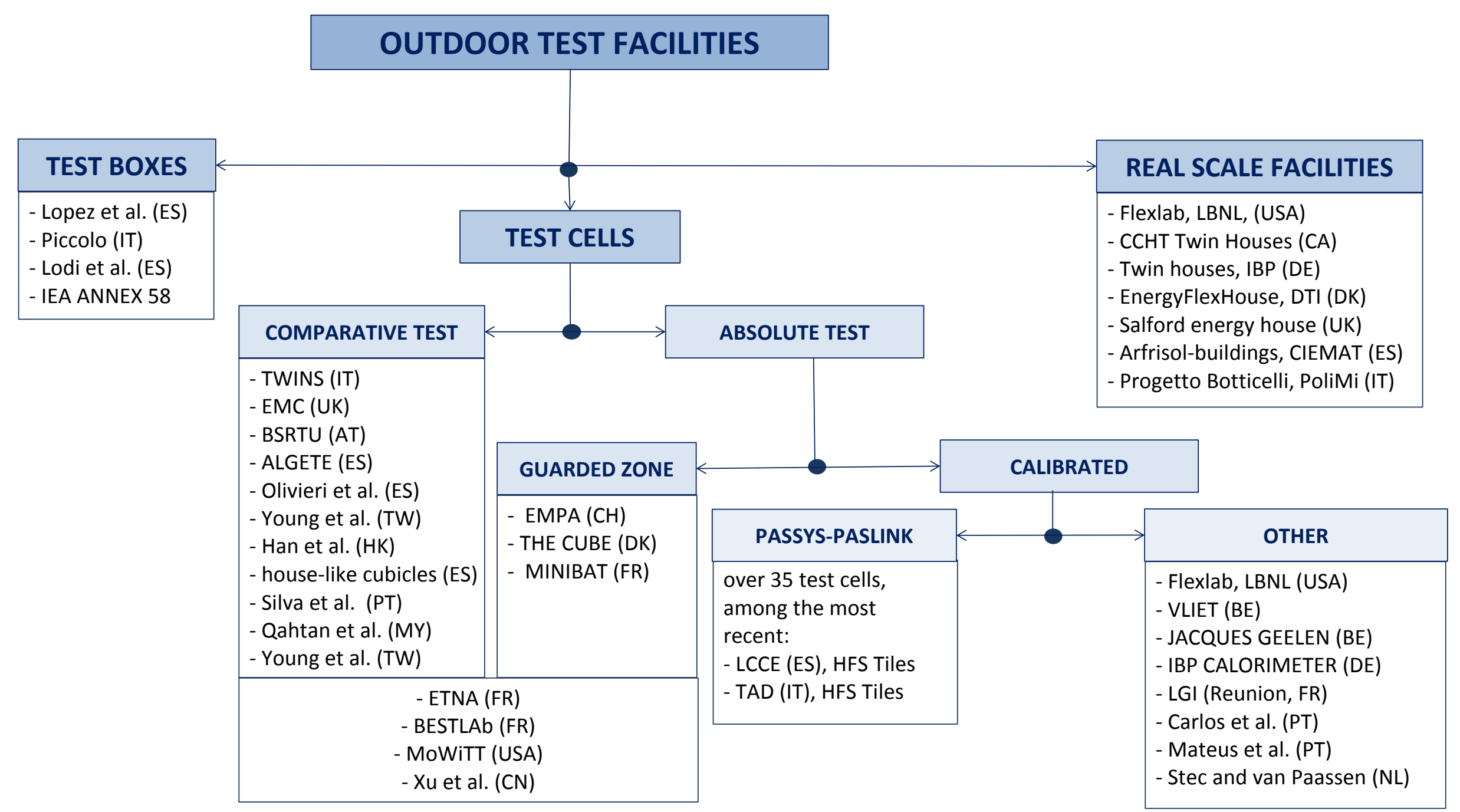

Figure 2. Classification of outdoor test facilities. When no name was explicitly given in available literature, the authors have reported the location or the authors of the paper where the facility is described. 


\begin{tabular}{|c|c|c|c|}
\hline $\begin{array}{l}\text { Name, location - } \\
\text { ref. }\end{array}$ & family & available specifications & examples of performed tests \\
\hline $\begin{array}{l}\text { TWINS, Turin (IT) - } \\
{[6],[32]}\end{array}$ & $\mathrm{CO}$ & $\begin{array}{l}\text { dimensions (WxLxH): } 1.6 \times 3.6 \times 2.5 \text { each room; volume: ca. } 14.4 \mathrm{~m}^{3} \\
\text { building materials: } 48 \mathrm{~mm} \text { sandwich panels in double painted } \\
\text { sheet-steel with expanded polyurethane, U-value of } 0.43 \\
\mathrm{Wm}^{2} \mathrm{~K}^{-1} \\
\text { HVAC system: ventilation and air conditioning systems are } \\
\text { completely independent, so to de-couple air change rates and air } \\
\text { temperature control }\end{array}$ & $\begin{array}{l}\text { thermal performance of a climate façade in } \\
\text { different configurations (venetian blinds/reflective } \\
\text { roller screen, mechanical and natural ventilation, } \\
\text { filters on the supply opening) }\end{array}$ \\
\hline $\begin{array}{l}\text { EMC TEST ROOM, } \\
\text { Bedfordshire (UK) - } \\
{[33]}\end{array}$ & $\mathrm{CO}$ & $\begin{array}{l}\text { dimensions (internal dimensions of each room, } \mathrm{W} \times \mathrm{LxH} \text { ): } \\
\text { ca.1.4x2.6x2.3; volume: ca. } 8.4 \mathrm{~m}^{3} \text { (inferred from drawings) } \\
\text { building materials: sandwich panels with plywood, } 100 \mathrm{~mm} \text { glass } \\
\text { fibre, } 25 \mathrm{~mm} \text { air gap and plasterboard }\end{array}$ & $\begin{array}{l}\text { empirical validation of whole-building energy } \\
\text { simulation software }\end{array}$ \\
\hline $\begin{array}{l}\text { BSRTU, Villach (AU) } \\
-[14]\end{array}$ & $\mathrm{CO}$ & $\begin{array}{l}\text { Dimensions of overall building }(\mathrm{WxL}): 10.3 \times 18.2 \mathrm{~m}^{2} \\
\text { HVAC-system - main room: T range } 20 \div 24^{\circ} \mathrm{C}, \mathrm{RH} \text { range } 30 \div 50 \% \text {; } \\
\text { humidity level inside the room adjusted by multiple } \\
\text { humidifying appliances }\end{array}$ & $\begin{array}{l}\text { hygrothermal performance of: pitched roofs, } \\
\text { ventilated crawlspaces, green flat roofs, masonry } \\
\text { walls with interior insulation }\end{array}$ \\
\hline $\begin{array}{l}\text { ALGETE DEMO } \\
\text { PARK, Algete (ES) - } \\
{[34]}\end{array}$ & $\mathrm{CO}$ & $\begin{array}{l}\text { dimensions of each unit (WxLXH): } 2.4 \times 3.0 \times 4 \\
\text { building materials: internal plasterboard layer }(1.2 \mathrm{~cm}) \text {, an air gap } \\
(7.5 \mathrm{~cm}) \text { and an external OSB layer }(2.5 \mathrm{~cm})+\text { internal steel } \\
\text { frame on a monolithic concrete slab }(10 \mathrm{~cm}) . \text { PVC door } \\
(0.9 \mathrm{~m} \times 2 \mathrm{~m}) \text { on the north and two windows }(0.6 \mathrm{~m} \times 0.9 \mathrm{~m}) \text { on the } \\
\text { east and south façades. } \\
\text { ventilation system: constant air change of } 1.5 \mathrm{ach} \text {, free-floating } \\
\text { conditions }\end{array}$ & $\begin{array}{l}\text { thermal performances of standard and Near } \\
\text { InfraRed reflecting building coatings (ceramic tiles, } \\
\text { acrylic paints and bituminous roof membranes) }\end{array}$ \\
\hline $\begin{array}{l}\text { HOUSE-LIKE } \\
\text { CUBICLES, Leida (ES) } \\
\text { - [35], [106], } \\
\text { [107], [108] }\end{array}$ & $\mathrm{CO}$ & $\begin{array}{l}\text { dimensions of each cell }(\mathrm{W} \times \mathrm{LxH}): 2.4 \times 2.4 \times 2.4 \\
\text { building materials: structure made of four mortar pillars with } \\
\text { reinforcing bars at the edges, hosting different types of } \\
\text { walls made of bricks and insulating materials. Concrete } \\
\text { base with crushed stones and reinforcing bars. Roof in } \\
\text { concrete precast beams and } 5 \mathrm{~cm} \text { of concrete slab, with } \\
\text { inclination of } 3 \% \text { and a double asphalt membrane. }\end{array}$ & $\begin{array}{l}\text { Thermal performance and analysis of total cost and } \\
\text { life cycle environmental impact of three opaque } \\
\text { element solutions using different insulation } \\
\text { materials and PCM }\end{array}$ \\
\hline
\end{tabular}




\begin{tabular}{|c|c|c|c|}
\hline & & $\begin{array}{l}\text { Heating/cooling system: an air conditioner and an electrical oil } \\
\text { radiator }\end{array}$ & \\
\hline $\begin{array}{l}\text { Young et al., Taipei } \\
\text { (Taiwan) - [39] }\end{array}$ & $\mathrm{CO}$ & $\begin{array}{l}\text { dimensions of each cell (WxLXH): } 2.3 \times 2.5 \times 3.1 \\
\text { building materials: two boards of cement and calcium silicate with } \\
65 \mathrm{~mm} \text { air gap, } 25 \mathrm{~mm} \text { XPS board and cement mortar coating; } \\
\text { U-value } \sim 0.3 \mathrm{Wm}^{2} \mathrm{~K}^{-1}\end{array}$ & characterisation of a heat insulation solar glass \\
\hline $\begin{array}{l}\text { THE CUBE, Aalborg } \\
\text { (DK) - [14], [44], [45] }\end{array}$ & G & $\begin{array}{l}\text { dimensions (WxLXH): } 5.17 \times 4.96 \times 5.58 \\
\text { HVAC system: recirculating piston flow with low impulse fabric } \\
\text { ducts (air velocity of } 0.2 \mathrm{~m} / \mathrm{s} \text { ); installed cooling and heating } \\
\text { units: } 10 \mathrm{~kW} \text { and } 2 \mathrm{~kW} \text { respectively }\end{array}$ & $\begin{array}{l}\text { thermal performance of a naturally/mechanically } \\
\text { ventilated double-skin façade, with operation of a } \\
\text { shading device }\end{array}$ \\
\hline $\begin{array}{l}\text { MINIBAT, Lyon (FR) } \\
-[14],[46]\end{array}$ & G & $\begin{array}{l}\text { dimensions of each room (WxLxH): } 3.1 \times 3.1 \times 2.5 \\
\text { building materials: cellular concrete (floor); plasterboard, } \\
\text { polystyrene, agglomerated wood (walls); plasterboard, } \\
\text { plywood, mineral wool, wood (ceiling) } \\
\text { heating/cooling system: one for each cell; different systems can } \\
\text { be installed and tested; air inlets and outlets can be } \\
\text { positioned in different ways } \\
\text { simulation of outdoor weather conditions and study of heat and } \\
\text { air transfers between two rooms }\end{array}$ & $\begin{array}{l}\text { studies on pollutant distribution and } \\
\text { efficiency of ventilation systems; hygrothermal } \\
\text { comfort and energy efficiency for different } \\
\text { ventilation systems and heating/cooling elements; } \\
\text { analysis of air jets from air inlets; studies on double- } \\
\text { skin façades and phase change materials; air flow } \\
\text { between two rooms through an open door }\end{array}$ \\
\hline
\end{tabular}




\begin{tabular}{|c|c|c|c|}
\hline $\begin{array}{l}\text { BESTLAB, Moret- } \\
\text { sur-Loing (FR) - [48], } \\
{[151]}\end{array}$ & G\&CO & $\begin{array}{l}12 \text { independent cells distributed on two floors, the upper ones } \\
\text { enabling tests on roof components. On each level there are } \\
\text { four cells south-oriented, one exposed to east and one to } \\
\text { west. The walls present a very low } U \text {-value }\left(U<0.1 \mathrm{Wm}^{2} \mathrm{~K}^{-1}\right) \\
\text { and are kept at a constant temperature by means of a } \\
\text { thermally guarded zone. }\end{array}$ & $\begin{array}{l}\text { PV-T collectors integrated to DHW production, } \\
\text { validation of simulation tools for low-energy } \\
\text { buildings }\end{array}$ \\
\hline $\begin{array}{l}\text { ETNA TEST } \\
\text { FACILITY, Paris (FR) - } \\
{[48],[49]}\end{array}$ & G\&CO & $\begin{array}{l}\text { area of each test cell: } 16 \mathrm{~m}^{2} \\
\text { HVAC system: full air heating systems installed in both cells, with } \\
\text { intake ducts near the ceiling and four supply air diffusers near } \\
\text { the floor oriented as the test cell length axis; PID thermostat } \\
\text { controller }\end{array}$ & $\begin{array}{l}\text { empirical validation of whole-building energy } \\
\text { simulation software }\end{array}$ \\
\hline $\begin{array}{l}\text { MOWITT, USA - } \\
{[50],[51],[52]}\end{array}$ & G\&CO & $\begin{array}{l}\text { heating/cooling system: electric heater, liquid to air heat } \\
\text { exchanger with measured heat flow rate and inlet/outlet } \\
\text { temperatures, interior skin of large area heat flow sensors. }\end{array}$ & electrochromic skylights \\
\hline $\begin{array}{l}\text { Xu et al., Wuhan } \\
\text { (China) - [53] }\end{array}$ & $\mathrm{G} \& \mathrm{CO}$ & $\begin{array}{l}\text { dimensions }(\mathrm{WxLxH}): 4.65 \times 3.4 \times 3.6 \\
\text { building materials: mineral wool board }(12 \mathrm{~mm}) \text { as thermal } \\
\text { insulation }\end{array}$ & $\begin{array}{l}\text { Characterisation of semi-transparent photovoltaic } \\
\text { modules }\end{array}$ \\
\hline $\begin{array}{l}\text { VLIET TEST } \\
\text { BUILDING, Leuven } \\
\text { (BE) - [14], [105], } \\
{[111],[116],[117]} \\
{[152],[153]}\end{array}$ & $\mathrm{CA}$ & $\begin{array}{l}\text { dimensions of overall building }(\mathrm{WxL}): 7.2 \times 25.2 \\
\text { building materials: metal structure, measurement bays separation } \\
\text { in wood-PUR-wood } \\
\text { HVAC-system: double air-conditioning system in partial } \\
\text { recirculation, possibility to simulate moisture production with } \\
\text { local steam humidifiers, inside-outside air pressured } \\
\text { differences obtainable via fans in the HVAC }\end{array}$ & $\begin{array}{l}\text { hygrothermal performance of: flat and ventilated } \\
\text { pitched roofs, ventilated cavities, double skin } \\
\text { façades, masonry walls with exterior or interior } \\
\text { insulation systems; rain load and rain water } \\
\text { penetration in masonry veneers; shading } \\
\text { performances of vertical and horizontal louver } \\
\text { systems }\end{array}$ \\
\hline $\begin{array}{l}\text { JACQUES GEELEN } \\
\text { LABORATORY, Arlon } \\
(\mathrm{BE})-[14]\end{array}$ & $\mathrm{CA}$ & $\begin{array}{l}\text { dimensions }(\mathrm{W} \times \mathrm{L} \times \mathrm{H}): 4.0 \times 3.0 \times 2.5 \\
\text { building materials: timber frame wood } \\
\text { heating/cooling system: floor radiating systems, radiating ceiling, } \\
\text { air supply; T range: } 5 \div 40^{\circ} \mathrm{C} \text {. Latent loads by water spraying or } \\
\text { vapour production }\end{array}$ & $\begin{array}{l}\text { analysis of the performance of: compact ventilation } \\
\text { system with heat recovery; solar cooling machine; } \\
\text { low inertia floor heating system; solar chemical } \\
\text { storage }\end{array}$ \\
\hline $\begin{array}{l}\text { CALORIMETRIC } \\
\text { TEST FACILITIY FOR } \\
\text { FAÇADES AND } \\
\text { ROOFS, Holzkirchen } \\
\text { (DE) - [14] }\end{array}$ & $\mathrm{CA}$ & $\begin{array}{l}\text { dimensions of specimen: up to } 3.5 \mathrm{~m} \times 3.8 \mathrm{~m} \\
\text { features: surfaces of the measurement-box are covered by water- } \\
\text { bearing absorbers, in order to rapidly remove solar gains; } \\
\text { possibility to orient and tilt the test cell }\end{array}$ & $\begin{array}{l}\text { first measurements started in } 2012 \\
\text { (to be published) }\end{array}$ \\
\hline
\end{tabular}




\begin{tabular}{|c|c|c|c|}
\hline $\begin{array}{l}\text { LGI CELL, Reunion } \\
\text { Island (FR) - [55], } \\
{[56],[57]}\end{array}$ & $\mathrm{CA}$ & $\begin{array}{l}\text { Volume: ca. } 30 \mathrm{~m}^{3} \\
\text { building materials - opaque walls: sandwich board } 80 \mathrm{~mm} \text { thick } \\
\text { (cement-fibre/polyurethane/cement fibre); roof ( } 20 \% \text { slope): } \\
\text { corrugated galvanized steel } 1 \mathrm{~mm} \text {, air layer } 280 \mathrm{~mm}, \mathrm{PCM} \\
5.26 \mathrm{~mm} \text {, plasterboard } 12.5 \mathrm{~mm} \text {; floor: concrete slabs } 80 \mathrm{~mm} \\
\text { on } 60 \mathrm{~mm} \text { thick polystyrene; window and glass door: } 8 \mathrm{~mm} \\
\text { clear glass and aluminium frame }\end{array}$ & $\begin{array}{l}\text { Thermal behaviour of a building roof equipped with } \\
\text { phase change materials (PCM), empirical validation } \\
\text { of a building thermal model, modelling and } \\
\text { empirical validation of thermal behaviour of roof- } \\
\text { mounted radiant barriers }\end{array}$ \\
\hline $\begin{array}{l}\text { Carlos et al., } \\
\text { Portugal - [17] }\end{array}$ & $\mathrm{CA}$ & $\begin{array}{l}\text { dimensions (WxLxH): } 2.2 \times 2.0 \times 2.5 \\
\text { building materials: metallic insulated container }\end{array}$ & $\begin{array}{l}\text { two double window systems under winter } \\
\text { conditions }\end{array}$ \\
\hline $\begin{array}{l}\text { Mateus et al., } \\
\text { Lisbon (PT) - [58] }\end{array}$ & $\mathrm{CA}$ & $\begin{array}{l}\text { building materials (from outside to inside) - exterior walls: plaster } \\
15 \mathrm{~mm} \text {, autoclaved aerated concrete } 300 \mathrm{~mm} \text {, plaster } 15 \mathrm{~mm} \text {; } \\
\text { roof: polyethylene } 2 \mathrm{~mm} \text {, slab } 140 \mathrm{~mm} \text {, autoclaved aerated } \\
\text { concrete } 75 \mathrm{~mm} \text {; floor: soil } 170 \mathrm{~cm} \text {, riprap } 25 \mathrm{~cm} \text {, ground slab } \\
10 \mathrm{~cm} \text {, screed } 5 \mathrm{~cm}\end{array}$ & $\begin{array}{l}\text { validation of thermal simulation of a double skin } \\
\text { naturally and mechanically ventilated test cell }\end{array}$ \\
\hline $\begin{array}{l}\text { Stec and van } \\
\text { Paassen, } \\
\text { Delft (NL) - [59] }\end{array}$ & $\mathrm{CA}$ & description missing & thermal performance of a double skin façade \\
\hline $\begin{array}{l}\text { PASLINK TEST } \\
\text { CELLS, several } \\
\text { locations in Europe - } \\
{[5],[13],[18],[60]} \\
{[62],[66],[67],[70]} \\
{[73]} \\
{[96]}\end{array}$ & $\mathrm{CA}$ & $\begin{array}{l}\text { dimensions (WxLxH): } 5 \times 2.76 \times 2.75 \text {; volume: ca. } 38.0 \mathrm{~m}^{3} \\
\text { building materials: rigid steel frame construction and stainless } \\
\text { steel casing }+400 \mathrm{~mm} \text { rigid polystyrene foam and mineral wool } \\
\text { - total U-value of } 0.10 \mathrm{Wm}^{2} \mathrm{~K}^{-1} \\
\text { positioning: different possibilities: six point foundation at a height } \\
\text { of about } 50 \mathrm{~cm} \text { from the ground; installed on a flat roof;... } \\
\text { HVAC system: heating (electric) and cooling (hydraulic) system, } \\
\text { for a range of indoor air temperatures: } 5 \div 45^{\circ} \mathrm{C}\end{array}$ & $\begin{array}{l}\text { hygrothermal performance of vertical and } \\
\text { horizontal opaque building elements (e.g. phase } \\
\text { change material walls or vegetal-fibres based } \\
\text { materials); thermo-optical performance of: } \\
\text { advanced window systems, shading devices, supply } \\
\text { air windows, ventilated double-skin façades, } \\
\text { window-components with integrated shading and } \\
\text { ventilation system; optimisation of control system } \\
\text { for solar shading; calibration of CFD and } \\
\text { hygrothermal simulation software tools }\end{array}$ \\
\hline
\end{tabular}




\section{OUTDOOR TEST CELL EXPERIMENTS}

Outdoor test cells are versatile facilities that can be used for a variety of purposes, such as:

o dynamic performance assessment of full size building components under real climatic conditions, with comparisons among different technological solutions

o validation of modules for building simulation models and new software tools

0 development of new methodologies of data analysis and system identification

\subsection{PERFORMANCE ASSESSMENT OF BUILDING COMPONENTS}

The wide variety of building components that can be tested include:

- innovative multi-glazed systems (advanced triple glazing, selective and diffusing glazing, etc.) [5]

- variable transmittance systems (glazed facades including blind systems, electro-chromic glazing, etc.) [5]

- framing system (curtain wall framing system, air supply window, etc.) [5]

- glazed façade elements (ventilated double façades, climatic facades, etc.)

- opaque elements (dynamic insulation walls, ventilated walls, PCM panels, green roofs, VIP (vacuum insulating panels, etc.)

- hybrid photovoltaic building integrated components [92]

- other products related to building industry (e.g. reflecting building coatings, controllers, etc.)

In the last years, active and passive solar building components have been studied for their potential of reducing the heating/cooling demand during the cold/warm season. However, analysing and documenting the behaviour of these objects is not a trivial task. For example, the performance of ventilated double façades depends on several parameters, such as the airflow rate in the cavity, the air inlet temperature, the height of the façade, the type and control strategy of the shading device etc. ([18], [93]). Real-scale testing with parametric analysis is thus necessary to accurately assess their performance, and to ensure that simulation programmes are capable of modelling the test component.

A selection of available studies conducted in outdoor test cells is here presented in order to better exemplify the broad range of scientific and industrial applications that can be covered by this type of experimental facilities.

The work by Serra et al. [6] conducted in the TWINS test cells in Turin, evaluates two different types of shading devices installed in a climate façade: a venetian blind with micro-perforated aluminium lamellas and a PVC reflective roller screen. Flamant et al. ([18], [94]) simulate the effects of solar absorption by the shading device located in the gap of a ventilated double façade (composed by two glazed layers separated by a ventilated air cavity, in which a shading device can be placed), by using controlled heating foils. The main objective is to investigate the heat transfer around a shading device, which is probably the contribution to the global heat transfer that is 
most difficult to describe and simulate. In a later work [95], the thermal and solar performances of an industrialized ventilated double façade were determined for different configurations of airflow rates in the cavity, different cavity widths and position of the shading device.

Diarce et al. [96] study a new type of opaque ventilated façade including a PCM in its external layer. The function of the PCM layer is that of increasing the thermal inertia and reducing the overheating of the façade in case of strong solar radiation. The experimental results are compared with simulations on four traditional façades carried out by Design Builder software. The works made by Goia et al. at the TWINS facilities [97-98] investigate the thermal performance of a prototype PCM glazing system and its impact on the indoor thermal comfort, comparing this solution to a reference double glazed unit filled with air. Goia et al. [97] focuses on the thermal performance of the test sample under summer, mid-season and winter conditions, while Goia et al. [98] includes a numerical simulation based on the measured data for the calculation of the Predicted Mean Vote in a typical office space. The tested PCM glazing prototype is a double glazed unit $(8 / 15 / 6 \mathrm{~mm})$ made of two clear glass panes filled with a commercial grade paraffin wax. The thermal performance of a ventilated façade with macroencapsulated PCM in its channel is evaluated by De Gracia et al. [99], in order to evaluate the potential of this constructive system to reduce the cooling loads of a single family house. Various operation modes are investigated in order to activate the PCM as a cold storage and to benefit from the night free cooling effect. The studies by Silva et al. [36]-[37] present the results of an experimental campaign on a window shutter containing organic paraffin PCM during the summer season. The prototype is compared to an internal window shutter with aluminium hollowed blades.

The performances of a supply air window is investigated by McEvoy et al. [19] and by Southall and McEvoy [100]. The device consists of «an inner and outer casement, the two being locked together by catches [...]. The plenum that is created is used as an air path for incoming airflow that enters the void through vents at the bottom of the outer window. Having been pre-heated by heat exchange with the warmth of the room and solar gain, the tempered air enters the building through vents at the top of the inner window» [19]. The air rises by stack effect and wind pressure or by mechanical means. In this way the window acts as both a heat reclaim and a passive solar device [100]. A ventilated shading screen was used to exclude solar radiation during the first phase of the experiment, then the screen was removed and the effect of solar radiation was quantified in terms of ventilation pre-heating. A similar strategy was studied by Carlos et al. [17] in a test cell in Portugal and by Heimonen in a PASLINK test cell in Finland [101].

The dual airflow window studied by Wei et al. [102] has two airflow paths in which the outdoor air is pre-heated by the exhaust indoor air by means of a glazed pane which acts as a heat exchanger. Qahtan et al. [38] evaluate the performance of a so-called Sustainable Glazed Water Film system. The idea consists in sweeping the outer surface of a glazed façade with a thin film of water in order to cool down the façade under intense solar irradiance conditions.

A window device with integrated shading and ventilation system (named LiLu from "Licht \& Luft", i.e. "light and air") was tested by Pfluger et al. [71]. The system comprises an insulated triple glazing, an adjustable shading lamella integrated in the gas-filled gap between the external and 
the middle pane and a heat recovery system located in the frame structure. This "plug \& play" system could be used in particular in refurbishments where it is necessary to reduce to a minimum the installation time and the disturbance to occupants (e.g. in school buildings or in social housing) [71]. Skylights made from prototype electrochromic glazings were tested in a test facility under ambient outdoor summer conditions in the Mobile Window Thermal Test (MoWiTT) Facility [52].

The work by Loutzenhiser et al. [10], conducted at EMPA facility, focuses on empirical validation of solar gain algorithms for a solar selective glazing unit with exterior venetian blinds and interior mini-blinds at two different slat positions. Experimental results were compared with predicted values obtained through simulations with EnergyPlus and HELIOS software tools. Further studies by Simmler \& Binder [103] investigate the total solar energy transmittance of a number of shading-glazing configurations, i.e. white, brown and white perforated slats at different tilt angles. At The Cube facility, Liu et al. [104] compare experimental data on a double-glazed façade equipped with a shutter and a shading system with simulation results obtained in BSim environment. The study aims at verifying a simplified calculation method to predict the energy and comfort performance of intelligent glazed facades with different control strategies.

Another relevant technology that can be studied via test cell experiments is the double-skin façade. Double-skin façades present an external glazed layer placed at a certain distance from the inner layer. These two panes enable air to circulate in the cavity of the façade, named buffer zone, channel, or air gap. This cavity is generally naturally ventilated [46]. Gavan et al. [46] studied the thermal performance of a double-skin façade provided with adjustable venetian blinds between the two skins, for different set-ups of the sun-shading device angle and ventilation rates. The façade is made of two aluminium frames. The internal frame is fixed, while the external one is divided into two parts and can be separately opened. Four openings for ventilation cover the whole width of the facade, at top and bottom of each of the two glass panes. The experiments were carried out at the Minibat test facility (Lyon, FR), which allows measurements under controlled thermal and radiative environment. The mechanically ventilated glass double façades studied at EMPA test facility by Manz et al. [42] are composed - from outside to inside - by an insulating glazing unit (the outer pane having solar protection properties and a low-emissivity coating), an outer air gap, a metallized shading screen, an inner air gap and a single pane with a low-emissivity coating on the outer side. Airflow between the gaps is possible through two openings at the top and bottom of the façade, each with a height of $2 \mathrm{~cm}$. In the first set-up, air is drawn from the lower part of the room into the double façade (supply) and the exhaust opening is near the ceiling. The purpose of the mechanical ventilation is to remove absorbed solar energy, particularly that on the shading screen, by convection so that it cannot heat up the adjacent room. In the second set-up, air is drawn from the upper part of the room into the double façade (supply) and the exhaust opening is near the floor. The influence of a correct modelling of the inlet temperature of naturally and mechanically ventilated multiple-skin facades is experimentally demonstrated by Saelens et al. [105]. The three investigated systems are a classical cladding system with external shading device, a mechanical flow multiple-skin facade and a naturally 
ventilated multiple-skin facade. A speed controllable circular duct ventilates the mechanically ventilated variant with interior air, the air flowing up from the bottom.

Not only glazed elements can be installed in outdoor test cells. Measurements of a dynamic insulation wall were conducted by Dimoudi et al. [62] in order to study the behaviour of breathing materials that let the air enter the room under a reasonable pressure difference between the interior and exterior. In particular, the experiments analysed the performance of the components under various differential pressure regimes between the interior and the exterior of the test cell and under controlled and floating internal air temperature.

Cabeza et al. [35] compare the insulation performance of opaque building components including foam polyurethane, mineral wool and polystyrene by measuring the energy consumption in the house-like cubicles at Leida (ES). In a recent work, Carreras et al. [106] use the same cubicles as a case study to apply a methodology for determining the optimal insulation thickness for external building surfaces. The approach is based on a multi-objective optimisation model that takes into account both the cost and environmental impact associated with the whole life cycle of the construction materials. The facilities served also to monitor annual electric energy consumptions as an input to a Life Cycle Assessment of opaque components integrating PCM (see de Gracia et al. [107] and Menoufi et al. [108]).

The experiment in Malta conducted by Caruana et al. [109] studied the potential applicability of hollow-core concrete blocks with enhanced thermal properties. Three concrete mix designs, including different percentages of expandable clay, perlite and basalt were compared to a reference hollow-core concrete wall (comparative approach). Values measured from the heat flow meter method were obtained with internal test cell temperature of $40^{\circ} \mathrm{C}$ and using i) the moving average technique according to ISO 9869:1994 - Part 1 and ii) a method based on infra-red thermography (an internal temperature of $30^{\circ} \mathrm{C}$ was chosen in this case).

Two types of ventilated wall components were investigated by Seferis et al. [20]: the 'Typical Ventilated Wall' and the 'Upgraded Ventilated Wall', the latter differing due to an additional thin radiant film added between the concrete slab and the air channel. The experiments were carried out at a PASLINK Test Cell equipped with a Pseudo-Adiabatic Shell (PAS), located close to Athens. The measurements of the two wall types were carried out simultaneously for comparative purposes. Each component covered half of the southern wall area and the indoor space was split in half by an insulation layer.

The ventilated wall studied by Pinard et al. [110] in a PASSYS test cell in Chambéry (FR) is designed to replace traditional heat emitters in buildings for indoor renovation, in particular where it is required to install nonvisible heat emitters (e.g. retirement homes, day-care centres, psychiatric hospitals). This design seeks to obtain a large and homogeneous emitting surface, operating both via radiation and convection heat transfer. The component combines insulation, heat emission, and wall surface finishes, lowering the installation costs. The main drawbacks lie in the occupation of internal space and the aesthetics of the vents. 
A recent study by Langmans and Roels [111] at the VLIET test facility compares four measuring techniques for the estimation of the ventilation rate behind two typical cladding systems, i.e. brick veneer and fibre cement sidings. The investigated approaches include tracer gas techniques, pressure measurements, air velocity measurements and a method based temperature and relative humidity registration.

Janssens and Hens studied four tiled roofs at the VLIET test facility [112]. The four test roofs differed in the material of the underlay (just below the tiles), in the presence of a vented cavity below the underlay and in the presence of a polyethylene air barrier. Two of the roofs were so-called vented roofs, containing a vented air cavity in between the thermal insulation and the underlay, while the two other test roofs were of the so-called compact type, meaning that the thermal insulation filled the structural cavity completely.

In the LGI test cell in the Reunion Island (tropical and humid climatic conditions), Miranville et al. [57] explored the performance of roof-mounted radiant barriers. Radiant barrier systems, which are thin membranes with very low values of emissivity, reduce the radiation heat transfer across the air gap into which they have been inserted. The same cell was used by Guichard et al. [55] to study the thermal behaviour of a commercial phase change material, consisting in a flexible sheet of $5 \mathrm{~mm}$ thickness made of $60 \%$ microencapsulated paraffin wax within a copolymer laminated on both sides with an aluminium sheet. The measurements were compared with the results obtained using a 1-D numerical thermal model based on finite difference.

The insulation effect of green roof systems and the resulting energy savings have been also explored by means of test cell experiments ([16], [73], [113]). The works conducted by Kotsiris \& Androutsopoulos [113] and by Kotsiris et al. [16] compare the thermal transmittance coefficients of different green roof systems with a conventional and an advanced insulated roof construction and investigate the relation between the estimated U-values and the substrate moisture content. In the work reported by Erkoreka [73], the PASLINK cell design is improved in order to test roof components under mono-dimensional heat flow hypothesis. Hygrothermal properties and heating/cooling energy savings using gravel and green roofs are quantified, distinguishing the cases of dry and irrigated green roofs.

A PASSYS test cell was used by Rode \& Grau ([114] and [115]) to observe the "moisture buffering effect" of building materials, that is the ability of building materials to smooth humidity variations in indoor spaces. Within the performed experiments, they controlled the moisture production (interchanging cycles with 12 hours of humidification followed by 12 hours of drying of the indoor air) and registered the resulting relative humidity variation, in order to mimic the typical exposures of building materials to domestic humidity sources. The results have been compared against computer simulations with the software BSim2000 [115]. The moisture response of building façades to wind-driven rain is investigated by Abuku et al. [116] at the VLIET test facility. The experimental set-up collected data on the relevant meteorological parameters, the impinging wind driven rain intensity, and the resulting material weight change of a calcium silicate building material sample. The measured wind driven rain intensity was used to perform numerical simulations of the moisture content/material weight change and make comparisons with the 
corresponding measurements. The Belgian facility was later used by Zerihum Desta et al. [117] to study the heat, air and moisture transfer through a light weight building envelope wall, when the interior finishing is varied. The envelope element, consisting of wooden studs with mineral wool insulation in between, presented at the outside a bituminous-impregnated soft wood fibreboard, followed by a cavity $(25 \mathrm{~mm})$ and a water resistant wooden multiplex board. The three tested sections had, as interior finishing: i) a wooden, air-open layer, ii) an uncoated gypsum board that is air tight but vapour open and iii) a multi-layer impermeable to water and vapour.

The European Project PV-Hybrid-PAS [118] investigated the potentialities of hybrid photovoltaic building integrated components in terms of combined heat recovery and electrical power production. A box called Test Reference Environment was constructed and inserted on the southern wall of a PASLINK test cell in order to measure with high accuracy the thermal energy obtained by convection and radiation exchanges at the rear of the PV module [119].

The study by Revel et al. [34] describes the experimental and numerical approach for the evaluation of thermal performances of standard and Near InfraRed reflecting building coatings. Three coloured materials have been considered: ceramic tiles, acrylic paints (both for façade application) and bituminous roof membranes. These materials have been installed as external layers on different test cells whose thermal similarity was previously assessed and quantified.

Argiriou et al. [120] tested the performance of a prototype neural controller connected to the electrical heating system of a PASSYS test cell close to Athens. The forecasting capabilities of neural networks, when fed with weather data and the thermal characteristics of the building, allow the shutdown of the heating system before incurring in overheating phenomena, thus achieving optimum energy use.

It must be noted that the performances of a tested component are always partially dependent on the characteristics of the facility by which the tests are carried out (e.g. thermal mass, orientation, relative dimensions). Thus, scaling up to full size buildings should be done with great caution.

As already mentioned, outdoor test cells can be used for purposes other than the assessment of performances of building components. For example, the work conducted by Goethals et al. [66] explores the impact of the air supply/exhaust configuration and thermal mass on the convective heat transfer during two mixed convection regimes. It is highlighted that existing correlations for convection strongly depend on the air flow rates, on the positioning of the supply and exhaust terminals in the test cell and on its thermal inertia.

\subsection{VALIDATION OF SIMULATION PROGRAMS}

Outdoor test cells are also used for the purpose of validating thermal models of single building components. The widespread use of these tools within the design and engineering communities requires a high level of confidence in these programs, that can best be encouraged by a rigorous development and validation effort combined with friendly user interfaces [121]. Validation is defined by Jensen [122] as «a rigorous testing of a program comprising its theoretical basis, software implementation and user interface under a range of conditions typical for the expected 
use of the program». Although each comparison between experimental and calculated performance covers a small region in an immense $\mathrm{N}$-dimensional parameter space, we would like to check that the results are not coincidental and represent the validity of the simulation elsewhere in the parameter space [121]. For this purpose, it is possible to improve the confidence in the programs combining several validation techniques [123-124].

As pointed out by Strachan [118], the advantage of using well-controlled outdoor experiments for novel building components to calibrate simulation models is that most of the parameters required by the model can be measured (with a certain accuracy) as opposed to a situation of a complete full scale building where part of the required parameters related to the component under study might be uncontrolled and /or difficult to measure. As a consequence, it is possible to reduce the number of parameters that need to be tuned via the calibration to reach a satisfactory match between measured and predicted data.

One of the aims of PASSYS project was to validate building energy models using a rigorous set of tests which investigate both single processes and so-called whole model validation (here meaning a model that comprehends different thermal processes and their interconnection, as defined in Jensen [122]) using analytical solutions, peer models and empirical data [125]. The PASSYS methodology has been tested in several case studies. In particular, Jensen [125] reports the results of a harmonized study where a reference wall was tested in eleven PASSYS test sites. The comparison of measurements and predictions included graphical display and residual analysis, making use of auto-correlation functions, density power spectra and cross-correlation functions. In the United States, The BESTEST validation standard has been under development by the National Renewal Energy Laboratory since the early 80's and has been restated as an ASHRAE standard [126]. The BESTEST method adopts a similar approach as the PASSYS method, using a combination of analytical and empirical tests to validate the individual components of the model and the overall building energy model accuracy. Over the years BESTEST has been expanded to apply to new applications of building energy models and to simulate more complicated HVAC systems.

Outdoor test cells experiments have been exploited for validating airflow and daylight models and for characterizing the thermal performance of single building components or control systems. In particular, an extensive validation work has been conducted in a PASSYS test cell in Athens, partly within the frame of PASCOOL CEC Research Programme. A wide array of configurations of single sided natural ventilation are studied by Dascalaki et al. [21] in a naturally-ventilated office building and in a PASSYS test cell facility. Ventilation measurements were done using a tracer gas $\left(\mathrm{N}_{2} \mathrm{O}\right)$ decay technique and wind speed measurements and comparisons are made against predictions by airflow networks models. The relationship between the air velocity at the opening and the bulk air flow rate measurements is studied in depth in [22]. Several single sided and cross-ventilation experiments conducted in Greece, Belgium and France are described in [23]. Results are compared against calculations in COMIS. The works by Tsangrassoulis et al. ([24], [25]) experimentally validate a model for daylight when adopting different shading strategies [24] and investigate the air flow and daylight transfer through the openings under single side ventilation configurations, when using movable vertical and horizontal louvers made of metallic sheets [25].

A method to calculate air flow through bottom-hung and sliding windows has been developed by 
Assimakopoulos et al [26]. The control algorithm can be implemented to control the opening length of the sliding window according to the temperature difference and the predefined air change rate. In a later work, controlling techniques for five windows with electrochromic properties are simulated within TRNSYS environment, and obtained results are compared in terms of heating and cooling loads of the test cell [27]. Various control strategies for electrochromic glazing systems i.e. scheduled ON-OFF controllers, a PID and advanced fuzzy controllers are further studied in [28].

At the EMPA test cell, Loutzenhiser et al. [127] study the validity of EnergyPlus and DOE-2.1E to model daylighting controls, such as mini-blinds, shades and exterior fins. Test rooms in the lowa Energy Center Energy Resource Station were monitored for each of the different daylighting control options and window orientations (south, west and east). The illuminance, light power and reheat coil power predicted by the building energy models were compared to each test room configuration. A later study by Loutzenhiser et al. [43] explores the ability of EnergyPlus, DOE-2.1E and IDA-ICE to incorporate a specific window design in the model. The cooling power required to maintain a near-constant temperature in presence of solar radiation was measured during the experiment and compared with results from the building energy simulation programs.

At the LGI test site, Mara et al. [56] checked the ability of a dynamic building simulation program, based on a RC network, to model the thermal behaviour of a simple test cell. A sensitivity analysis technique in the frequency domain was applied to state the reliability of the numerical predictions.

Outdoor test cells and buildings are large and complex experimental objects. A wide variety of unknowns can result in discrepancies between numerical and experimental results [128]. In literature the most recurrent sources of discrepancies are claimed to be:

- infiltration rates, one of the most influential variables on the space heating demand of a test cell [122] or an energy efficient house [129]. This effect becomes negligible in case a two-stage rubber sealing is implemented on the door and all gaps [40] and walls are treated with air-tight finishing materials or layers;

- imprecise information on the exact design details, material properties, and construction in the field, which result in uncertainties about how closely the model is representing the actual experimental object ([130 - 132], [121]). In particular, it is usually assumed that material conductivities are fixed values, while they actually present a slight dependence with temperature, which can be typically around $5 \%$ per $10^{\circ} \mathrm{C}$ variations for insulation materials [133]. Material properties should be always measured and not merely obtained from handbooks [122]. Minor effects can derive from other simplifications, such as neglecting the effect of dirt on thermo-optical properties of glazed elements [122];

- thermal bridges, which can hardly be completely avoided or properly described ([122], [132]). They usually occur at the wall where the test sample is installed and at the edges of the entrance door of the test cell [40];

- erroneous or lacking measurements of local climate conditions ([129], [130]). As noticed by Judkoff and Neymark [131], very few experiments measure precisely the fraction of direct, 
diffuse, and ground reflected radiation, all of which are inputs needed by many building energy simulation programs. Manz et al. [40] chose time intervals with overcast sky in order to deal with less fluctuating boundary conditions;

- surface heat transfer coefficients, which need to be accurately chosen among the wide variety of available empirical correlations in order to better describe the specific physical configuration (e.g. considering the presence of recirculating fans which increase indoor air velocities, or estimating the variations of the external surface heat transfer coefficient with the wind speed and direction) ([130], [132],);

- measurement uncertainties and spatial and temporal discretisation, an issue that has become less crucial with the fast improvement and the cost-effectiveness of instrumentation;

- thermal mass: as pointed out by Loutzenhiser et al. [41], cooling power predictions obtained via simulations are more sensitive to boundary conditions in case they are conducted on a light-structure test cell compared to massive buildings, due to the small thermal mass (and time constant) of the former case. This could result in larger discrepancies between measured and predicted data, penalizing the building energy simulation programs. Large discrepancies between the simulated and measured values of the global (convective and radiative) heat transfer coefficient were found by Zanghirella et al. [32], who noted that in the presence of high solar radiation, the internal surfaces of the test cell envelope reach temperatures that are close to those of the inner glass of the tested active façade.

- other important factors such as the heat recovery efficiency of the ventilation system and the exact determination of internal heat gains [129] (which in the case of test cells usually consist of the heat loads due to recirculation fans and contributions from the electrical equipment)

- so-called internal errors [121] deriving from model assumptions, numerical approximations and coding. Examples of model assumptions in the case of double-skin façade systems [134] are: use of 1D instead of 3D geometry (neglecting vertical temperature gradient, heat transfer in the lateral direction and 3D heat transfer in the corners), simplifications in the description of the shading devices (geometry of slats, reflection of short and long wave radiation) and exclusion of other physical phenomena such as minor air leakages in the system, which would be practically impossible to describe. According to Park et al. [134] the above-mentioned simplifications cannot be tracked individually, but they can altogether be offset and compensated for by the parameter values that the calibration produces. The lumped models can thus be easily constructed based on a "grey box" approach, i.e. partly based on the lumped descriptions of dominant physical processes, and augmented by calibration parameters to make up for the simplifications.

One of the suggested methods for obtaining more informative levels of validation is to increase the density of output-to-data comparisons, for example comparing temperature and energy results at various time scales ranging from sub-hourly to annual values [121]. However, it is worth remarking that the level of detail on the experimental data cannot be arbitrarily refined. As noticed by Janssens et al. [14], the lay-out of the measuring equipment within each test wall is always a trade-off between the accurate description of the physical phenomenon and the costs involved in sensors, computer equipment and data processing and interpretation. In addition, the 
measuring equipment itself can influence the hygrothermal behaviour of the test cell (creation of thermal bridges, local thermal loads etc.).

Even when a code is validated, it is important to remember that it does not necessarily represent truth. It does represent «a set of algorithms that have been shown, through a repeatable procedure, to perform according to the current state of the art» [121]. In particular, the behaviour of building occupants can largely influence the final energy usage, such as through actions on temperature set points, heating/cooling schedules and modification of the activities performed in the building. The review done by Ryan and Sanquist [135] on validation of building energy modelling tools investigates so-called "idealized studies", that consider only the parameters related to the building and HVAC system and "realistic studies", which include also the occupancy effects. While the first ones typically use a controlled outdoor test cell, in the "realistic studies" the model is compared to actual metering and auditing data from residential and commercial buildings.

Table 2 summarises the examined outdoor test cell studies for performance assessments of building components and for software validation and it is complementary to Table 1 on test cells characteristics. 
Table 2. Summary of test cell studies for performance assessments of building components and software validation. When no name is associated to the test cell, only the country is reported.

\begin{tabular}{|c|c|c|c|}
\hline Type of component/test & Outdoor test cell & References & $\begin{array}{l}\text { Year of } \\
\text { publication }\end{array}$ \\
\hline Climate façade & TWINS (IT) & Serra et al. [6] & 2010 \\
\hline Ventilated double façade & PASLINK-PAS (BE) & $\begin{array}{l}\text { Flamant et al. [18] } \\
\text { Flamant et al. [95] }\end{array}$ & $\begin{array}{l}2004 \\
2004\end{array}$ \\
\hline Ventilated façade with PCM & PASLINK-HFS (ES) & Diarce et al. [96] & 2013 \\
\hline PCM glazing system & TWINS (IT) & Goia et al. [97]-[98] & $2013-2014$ \\
\hline Ventilated facade with PCM & $\begin{array}{l}\text { house-like cubicles } \\
\text { (ES) }\end{array}$ & De Gracia [99] & 2013 \\
\hline Window shutter with PCM & Portugal & Silva et al. [36]-[37] & 2015 \\
\hline \multirow[t]{3}{*}{ Supply air window } & PASSYS (UK) & $\begin{array}{l}\text { Mc Evoy et al. [19] } \\
\text { Southall and Mc Evoy [100] }\end{array}$ & $\begin{array}{l}2003 \\
2006\end{array}$ \\
\hline & Portugal & Carlos et al.[17] & 2010 \\
\hline & PASLINK (FI) & Heimonen et al. [101] & 2004 \\
\hline Dual airflow window & Harbin $(\mathrm{Cl})$ & Wei et al. [102] & 2010 \\
\hline Sustainable Glazed Water Film & Malaysia & Qahtan et al. [38] & 2011 \\
\hline LiLu integrated window & PASLINK (AT) & Pfluger et al. [71] & 2010 \\
\hline Electrochromic skylights & MoWiTT & Klems JH [52] & 2001 \\
\hline Venetian blinds and mini-blinds & EMPA (CH) & $\begin{array}{l}\text { Loutzenhiser et al. [10] } \\
\text { Simmler and Binder [103] }\end{array}$ & 2008 \\
\hline $\begin{array}{l}\text { double-glazed façade with a } \\
\text { shutter and a shading system }\end{array}$ & The Cube (DK) & Liu et al. [104] & 2014 \\
\hline Double-skin façade & MINIBAT (FR) & Gavan et al. [46] & 2010 \\
\hline Ventilated glass double façade & EMPA (CH) & Manz et al. [42] & 2004 \\
\hline $\begin{array}{l}\text { Naturally and mechanically } \\
\text { ventilated multiple-skin facades }\end{array}$ & VLIET (BE) & Saelens et al. [105] & 2004 \\
\hline Dynamic insulation wall & PASLINK-PAS (GR) & Dimoudi et al. [62] & 2004 \\
\hline \multirow[t]{2}{*}{ Insulation materials } & \multirow{4}{*}{$\begin{array}{l}\text { house-like cubicles } \\
\text { (ES) }\end{array}$} & Cabeza et al. [35] & 2010 \\
\hline & & Carreras et al. [106] & 2015 \\
\hline \multirow[t]{2}{*}{ Walls and roofs including PCM } & & de Gracia et al. [107] & 2010 \\
\hline & & Menoufi et al. [108] & 2013 \\
\hline hollow-core concrete blocks & Malta & Caruana et al. [109] & 2014 \\
\hline \multirow[t]{2}{*}{ Ventilated wall } & PASLINK-PAS (GR) & Seferis et al. [20] & 2011 \\
\hline & PASSYS (FR) & Pinard et al. [110] & 2012 \\
\hline $\begin{array}{l}\text { measuring techniques in } \\
\text { ventilated cavities }\end{array}$ & VLIET (BE) & Langmans [111] & 2015 \\
\hline Tiled wooden-frame roofs & VLIET (BE) & Janssens and Hens [111] & 2007 \\
\hline Roof + phase change materials & LGI cell (FR) & Guichard et al. [55] & 2014 \\
\hline Roof-mounted radiant barriers & LGI cell (FR) & Miranville et al. [57] & 2003 \\
\hline \multirow[t]{2}{*}{ Green roofs } & PASLINK-HFS (PO) & Erkoreka [73] & 2012 \\
\hline & PASLINK-PAS (GR) & $\begin{array}{l}\text { Kotsiris et al. [16] } \\
\text { Kotsiris \& Androutsopoulos } \\
{[113]}\end{array}$ & $\begin{array}{l}2012 \\
2010\end{array}$ \\
\hline Moisture buffering effects & PASSYS (DK) & Rode \& Grau [114], [115] & 2003 \\
\hline Wind driven rain on façades & VLIET (BE) & Abuku et al. [116] & 2009 \\
\hline
\end{tabular}




\begin{tabular}{|c|c|c|c|}
\hline $\begin{array}{l}\text { Interior finishing and heat, air } \\
\text { and moisture transfer }\end{array}$ & VLIET (BE) & Zerihum Desta et al. [117] & 2011 \\
\hline Hybrid BIPV & PASLINK cells + box & Bloem [119] & 2008 \\
\hline Near Infra-Red coatings & $\begin{array}{l}\text { Algete Demo Park } \\
\text { (ES) }\end{array}$ & Revel [34] & 2014 \\
\hline $\begin{array}{l}\text { Air supply/exhausts and thermal } \\
\text { mass }\end{array}$ & PASLINK-PAS (BE) & Goethals et al. [66] & 2012 \\
\hline Neural controller & PASLINK-PAS (GR) & Argiriou et al. [120] & 2000 \\
\hline $\begin{array}{l}\text { Software validation of a test } \\
\text { reference wall }\end{array}$ & PASSYS cells & Jensen [125] & 1993 \\
\hline $\begin{array}{l}\text { Single sided and cross- } \\
\text { ventilation } \\
\text { Daylight and airflow models for } \\
\text { shading systems } \\
\text { Airflow and solar gain control } \\
\text { for traditional and } \\
\text { electrochromic windows }\end{array}$ & PASSYS (GR) & $\begin{array}{l}\text { Dascalaki et al. [21] } \\
\text { Dascalaki et al. [22] } \\
\text { Dascalaki et al. [23] } \\
\text { Tsangrassoulis et al. [24] } \\
\text { Tsangrassoulis et al. [25] } \\
\text { Assimakopoulos et al. [26] } \\
\text { Assimakopoulos et al. [27] } \\
\text { Assimakopoulos et al. [28] }\end{array}$ & $\begin{array}{l}1995 \\
1996 \\
1999 \\
1996 \\
1997 \\
2002 \\
2004 \\
2007\end{array}$ \\
\hline $\begin{array}{l}\text { Daylight controls, window } \\
\text { modelling }\end{array}$ & EMPA (CH) & $\begin{array}{l}\text { Loutzenhiser et al. [127] } \\
\text { Loutzenhiser et al. [43] }\end{array}$ & $\begin{array}{l}2007 \\
2009\end{array}$ \\
\hline $\begin{array}{l}\text { Empirical thermal model of a } \\
\text { test cell }\end{array}$ & LGI cell (FR) & Mara et al. [56] & 2001 \\
\hline
\end{tabular}

\section{PERFORMANCE INDICATORS FOR GLAZED BUILDING COMPONENTS DEVELOPED BY MEANS OF OUTDOOR TEST CELLS}

A considerable number of performance indicators has been identified and univocally defined in international standards. Most of the tests required to determine such indicators are obtained in laboratories with fully controlled boundary conditions and relatively simple procedures [136].The calculation methods of the thermal transmittance of windows, doors and shutters are specified in the standard ISO 10077-1:2006. The standard applies to different types of glazing, opaque panels within the window or door, various types of frames and, where appropriate, the additional thermal resistance introduced by different types of closed shutter, depending on their air permeability. The analysis of the physical variables influencing the $U$-value of a window shows that several factors are involved [29], such as:

- indoor and outdoor temperatures, which in turn modify a) the physical properties of the air trapped inside a double glazing component (density, dynamic viscosity and conductivity) and b) radiative and convective heat exchange in the gap of the double glazing

- wind velocity and indoor air velocity, causing variations of the convective heat exchange coefficients and internal and external surfaces

- long-wave exchange with the external environment 
Baker [29] argues that the non-linear variation of U-value with these parameters should be taken into account in sequence and analysis methods, so to define appropriate standardized boundary conditions for the testing of components. Frank and Binder [137] found that the exterior heat exchange coefficient was in the range between 10 and $15 \mathrm{Wm}^{2} \mathrm{~K}^{-1}$, which is significant lower than the commonly used value of $25 \mathrm{Wm}^{2} \mathrm{~K}^{-1}$. However, simple calculations show that the influence of the external heat coefficient becomes negligible in case of well-insulated opaque walls (e.g. for a wall presenting a U-value of $0,18 \mathrm{Wm}^{2} \mathrm{~K}^{-1}$, a decrease of the external heat exchange coefficient down to $10 \mathrm{Wm}^{2} \mathrm{~K}^{-1}$ will cause a decrease of the transmittance value by just $1 \%$ ). As regards the performance assessment procedure, the $U$-value is calculated in steady-state conditions, which is seldom the case of real operating conditions. The periodic thermal transmittance reported in UNI 13786 defines dynamic properties of opaque elements, but does not provide similar indicators for glazed elements.

The U-value is no more sufficient to describe the thermal behaviour of dynamic glazed components such as ventilated double façades and supply air windows, where the heat balance must include the heat flux due to the air flowing in the window cavity. Advanced building components thus require specific performance indices which should be defined prior to the experiment in order to ensure the acquisition of all involved physical quantities. For each of these situations it is necessary to develop ad hoc, non-standardized procedures involving a large use of delicate instrumentation and advanced and multidisciplinary scientific knowledge [136]. The scientific community has already proposed new performance parameters in order to characterize these new elements, for example suggesting an effective U-value [60] or an equivalent $U$-value [18]. These indices have been derived from energy balances that consider the heat fluxes driven by airflows through the supply air window and the ventilated double façade, respectively. Two indices named pre-heating efficiency and dynamic insulation efficiency were used by Corgnati et al. [93] to describe the dynamic behaviour of the climate façade. At present, the proposed indices have not been adopted yet in the international standards, due to the lack of a common agreement on performance assessment procedures and due to the difficulties in finding performance criteria that can be transversally applied to different types of advanced glazed components.

The CEN TC89 WG13 "In-situ thermal performance of construction products, building elements and structures" [138] started working in 2010 with the aim of elaborating "a procedure, or procedures, to derive in-situ test data that will complement the declared or design thermal performance value of construction products, building elements and structures established by conventional steady state methods, e.g. in accordance with EN 10456 and EN 6946». The working group is formed by more than 40 participants and involves 13 countries [139].

\section{SYSTEM IDENTIFICATION TECHNIQUES FOR EXTRACTING PERFORMANCE INDICATORS}

Test facilities are dynamic systems subject to rapidly varying boundary conditions and different types of disturbances (such as the measurement white noise). When performing test cell 
experiments with presence of solar radiation, neither the thermal transmittance nor the total solar energy transmittance can be measured directly because of the simultaneous influence of different heat transfer mechanisms, such as free convection, thermal radiation, short wave solar radiation and conduction. However, these quantities can be inferred indirectly based on the measurement of the net heat flow through the building component [140]. In order to obtain these important values, the first step always consists of modelling the test facility, that is giving a mathematical description of the physical systems and processes involved. Every model is a trade-off between two needs, that is on one side simplifying the reality and on the other side achieving the necessary information with good accuracy. Not all approaches are equivalent in terms of required test duration and computing effort: averaging methods (such as the one described in standard ISO 9869 [141]) have given way to dynamic system identification techniques, which reduce the test period, improve accuracy and allow for estimating confidence intervals [142]. By using dynamic evaluation techniques, effects caused by heat accumulation in the test cell and test sample are properly treated and it is possible to distinguish noise from useful information [143], obtaining accurate estimates of steady state properties despite the fluctuating outdoor weather conditions [144]. However, care must be taken in order to correctly interpret the physical meaning of the obtained results, especially in case of very perturbed data [145] or when the choice of the model brings along consistent differences in estimates [146]. A detailed description of system identification techniques is nevertheless beyond the purpose of this paper. An introduction to linear and time invariant models for describing the thermal characteristics of building components is given by Jiménez et al. [147], while a thorough review of models has been done by Jiménez and Madsen [148]. The mathematics of time series analysis is rigorously presented in Madsen [149], while an extensive dissertation on system identification techniques is gathered in a JRC publication [150] dated 1994.

\section{LIMITATIONS OF OUDOOR TEST CELL EXPERIMENTS}

Outdoor test cells suffer from several limitations, some of technical nature and others related to the lack of standard procedures and the know-how management:

Technical aspects

- dimensional limits: only components that fit the test cell aperture can be studied ([5])

- design and construction costs, which can be justifiable just in view of a rather intense use of the facility [5]. The life of the test cell should also be considered, since structural and damp problems may occur after some years [15].

- longer testing periods compared to steady-state laboratory tests, although test cell experiments provide more information on the dynamic performance of the test sample [5]

- need for a regular maintenance of the facility, which is exposed to the external climate and thus subject to material degradation (e.g. aging of insulation panels) and rain penetration [30].

Standardisation and know-how transfer management

- lack of a testing standard (CEN, ISO or national) that offers manufacturers of building components national/international certifications of their products 
- need for a responsible in charge, ensuring exhaustive know-how transfer. As reported within IQ-Test project «Once key persons are gone, it may be very difficult and sometimes even nearly impossible to build up the required knowledge within a reasonable timing and with a reasonable cost» [50]

Strachan [118] points out that the actual behaviour of building components, when integrated into full-scale buildings, is also highly dependent on specific operational conditions. For example, the exploitation of recovered heat will depend on the real building type, the operational regime, the external climate, the presence of other heat sources, etc. As a consequence, the temporal matching of low-grade heat supply offered by the heat recovery system with the building heating demand must be studied for each individual case by means of building energy simulations. Another example is represented by the operation of shading systems, which depends on the control options, the effect of high/low transmission states, etc.

In conclusion, modifications of the model or the simulation tool should take into account which processes are of major importance in test cells (e.g. thermal bridges, temperature-dependent conductivities etc.) compared to real buildings, where the user behaviour can play a key role.

\section{CONCLUSIONS}

Outdoor test cell facilities have been extensively used by the scientific community for the characterisation of building envelope components. We propose in this paper a classification of outdoor test cells based on their design concept, that is: "Comparative test" (meant for assessing the performance of a component with respect to a reference element or configuration), "Absolut test" (meant for assessing the performance of a component on the basis of monitored boundary conditions). A further sub-classification of absolute test cells is made in the paper on the basis of the construction approach used to minimize heat loss/gain through the cell envelope, i.e. "guarded test cells" and "calibrated test cells".

The great variety of building concepts and types of tests that can be performed represent at the same time the strength and the weakness of test cell experiments: on one side specific scientific purposes can be pursued (e.g. taking into account the challenges posed by local climate conditions), on the other side the lack of standardized procedures still hinders the wide penetration of this kind of tests in the building market. It is in fact difficult to compare the performance assessment determined with different cells and methodologies. The PASSYS-PASLINK network, started in 1986 and still ongoing within INIVE EEIG, has proposed a harmonized test methodology that includes both the hardware (test cell design, choice of the instrumentation etc.) and the software (data analysis techniques, modelling tools) needed for a complete characterisation of a building component. However, new test facilities have been recently constructed with different design concepts, such as comparative and/or guarded cells. In many cases, the available scientific literature provides incomplete information on the test cell characteristics and operation, reducing the replicability and the ease of interpretation of the performed tests. Whatever the chosen concept, great care should be taken not only at the design and construction phases, but also at the long-term maintenance of the facility, which is exposed to 
the external climate and thus subject to material degradation. Since test facilities are complex objects requiring high-level, multidisciplinary expertise, an efficient know-how management is fundamental for a long-term utilisation of the cell.

This paper tries to orient the reader among the most interesting experiences on outdoor test cells. Since new building envelope components are climate responsive and increasingly energy efficient, outdoor test cells should be designed together with commonly agreed testing methodologies able to interpret the large amount of information provided by outdoor experiments. 


\section{AKNOWLEDGEMENTS}

We would like to thank Livio Mazzarella, Marco Perino, Giuseppina Alcamo, Maurizio De Lucia, Hans Bloem, Aitor Erkoreka, Dominique Derome, Bruno Binder and Roger Vonbank for the insights and the fruitful discussions on potentialities and limits of use of outdoor test cell facilities. The present work has been partially developed within the framework of IEA EBC Annex 58 - 'Reliable Building Energy Performance Characterisation Based on Full Scale Dynamic Measurements'.

\section{REFERENCES}

[1] Marc LaFrance et al. Technology Roadmap: Energy efficient building envelopes, OECD/IEA, 2013

[2] Walsh B, Urban B, Herkel S. Innovation for Better Buildings: An Opportunity Disguised as Meltdown, Nth Power and Fraunhofer Institute, 2009.

[3] Clarke JA, Janak M and Ruyssevelt P. Assessing the overall performance of advanced glazing systems. Solar Energy 1998, 63 (4), 231-241.

[4] IEA ECBCS Annex 50 - Prefabricated Systems for Low Energy Renovation of Residential Buildings http://www.empa-ren.ch/A50.htm (last access on 27/01/2015)

[5] Strachan PA and Vandaele L. Case studies of outdoor testing and analysis of building components. Building and Environment 2008, 43, 129-142.

[6] Serra V, Zanghirella F and Perino M. Experimental evaluation of a climate façade: Energy efficiency and thermal comfort performance. Energy and Buildings 2010, 42, 50-62.

[7] ISO 8990:1994 - Determination of steady-state thermal transmission properties - Calibrated and guarded hot box.

[8] ISO 12567-1:2010 - Thermal performance of windows and doors - Determination of thermal transmittance by the hot-box method - Part 1: Complete windows and doors.

[9] Strachan PA and Baker PH. Outdoor testing, analysis and modelling of building components. Building and Environment 2008, 43, 127-128.

[10] Loutzenhiser PG, Manz H, Carl S, Simmler H and Maxwell GM. Empirical validations of solar gain models for a glazing unit with exterior and interior blind assemblies. Energy and Buildings 2008, 40, 330-340.

[11] Roels S. The IEA EBC Annex 58-project on 'Reliable Building Energy Performance Characterisation Based on Full Scale Dynamic Measurements', Seminar on Real building energy performance assessment, 16 April 2014 - Gent, Belgium.

[12] IEA ECBCS Annex 43 - Testing and Validation of Building Energy Simulation Tools. http://www.ecbcs.org/annexes/annex43.htm (last access on 27/01/2015)

[13] BBRI. The PASSYS Test Cells . A common European outdoor test facility for thermal and solar building research, 1990.

[14] Janssens A, Roels S and Vandaele L. Full scale test facilities for evaluation of energy and hygrothermal performances. International DYNASTEE-INIVE Workshop, Brussels, 2011.

[15] Erkoreka A, Escudero C, Flores I, Garcia C and Sala JM. Upgrading and calibration of two PASLINK test cells. Evaluation through the "IQ-TEST" round-robin test. Conference proceeding from "Dynamic Analysis, Simulation and Testing applied to the Energy and Environmental Performance of Buildings", 12-14 October 2005, Athens. 
[16] Kotsiris G, Androutsopoulos A, Polychroni E and Nektarios PA. Dynamic U-value estimation and energy simulation for green roofs. Energy and Buildings 2012, 45, 240-249.

[17] Carlos JS, Corvacho H, Silva PD, Castro-Gomes JP. Real climate experimental study of two double window systems with preheating of ventilation air. Energy and Buildings 2010, 42, 928934.

[18] Flamant G, Loncour X, Wouters P and L'heureux D. Ventilated double façades - Real-scale testing of ventilated double façades performance assessment in PASLINK test cell. Belgian Building Research Institute (BBRI), 2004.

[19] McEvoy ME, Southall RG and Baker PH. Test cell evaluation of supply air windows to characterise their optimum performance and its verification by the use of modelling techniques. Energy and Buildings 2003, 35, 1009-1020.

[20] Seferis P, Strachan P, Dimoudi A, Androutsopoulos A. Investigation of the performance of a ventilated wall. Energy and Buildings 2011, 43, 2167-2178.

[21] Dascalaki E, Santamouris M, Argiriou A, Helmis C, Asimakopoulos DN, Papadopoulos K, Soilemes A. Predicting single sided ventilation rates in buildings, Solar Energy 1995, 55, 327341.

[22] Dascalaki E, Santamouris M, Argiriou A, Helmis C, Asimakopoulos DN, Papadopoulos K, Soilemes $A$. On the combination of air velocity and flow measurements in single sided natural ventilation configurations. Energy and Buildings 1996, 24, 155-165.

[23] Dascalaki E, Santamouris M, Bruant M, Balaras CA, Bossaer A, Ducarme D, Wouters P. Modeling large openings with COMIS. Energy and Buildings 1999, 30, 105-115.

[24] Tsangrassoulis A, Santamouris M, Asimakopoulos DN. Theoretical and experimental analysis of daylight performance for various shading systems. Energy and Buildings 1996, 24, 223-230.

[25] Tsangrassoulis A, Santamouris M, Asimakopoulos DN. On the air flow and radiation transfer through partly covered external building openings. Solar Energy 1997, 61, 6, 355-367.

[26] Assimakopoulos MN, Tsangrassoulis A, Mihalakakou G, Santamouris M, Jauré S. Development of a control algorithm to optimize airflow rates through variable size windows. Energy and Buildings 2002, 34, 363-368.

[27] Assimakopoulos MN, Tsangrassoulis A, Guarracino G, Santamouris M. Integrated energetic approach for a controlable electrochromic device. Energy and Buildings 2004, 36, 415-422.

[28] Assimakopoulos MN, Tsangrassoulis A, Santamouris M, Guarracino G. Comparing the energy performance of an electrochromic window under various control strategies. Building and Environment 2007, 42, 2829-2834.

[29] Baker PH. Evaluation of round-robin testing using the PASLINK test facilities. Building and Environment 2008, 43, 181-188.

[30] Bloem JJ. Final Report on Inspection of the European Outdoor Thermal Test Facility - Work Package 1, IQ-Test PASLINK EEIG (2003).

[31] Olivieri L, Caamaño-Martin E, Olivieri F, Neilab J. Integral energy performance characterization of semi-transparent photovoltaic elements for building integration under real operation conditions. Energy and Buildings 2014, 68, 280-291.

[32] Zanghirella F, Perino $M$ and Serra V. A numerical model to evaluate the thermal behaviour of active transparent façades. Energy and Buildings 2011, 43, 1123-1138. 
[33] Lomas KJ, Eppel H, Martin CJ and Bloomfield DP. Empirical validation of building energy simulation programs. Energy and Buildings 1997, 26, 253-275.

[34] Revel GC, Martarelli M, Emiliani M, Celotti L, Nadalini R, De Ferrari A, Hermanns S and Beckers E. Cool products for building envelope - Part II: Experimental and numerical evaluation of thermal performances. Sol. Energy 2014, 105, 780-791.

[35] Cabeza LF, Castell A, Medrano M, Martorell I, Pérez G, Fernández I. Experimental study on the performance of insulation materials in Mediterranean construction. Energy and Building 2010, 42, 630-636.

[36] Silva T, Vicente R, Rodrigues F, Samagaio A, Cardoso C. Performance of a window shutter with phase change material under summer Mediterranean climate conditions. Applied Thermal Engineering 2015, 84, 246-256.

[37] Silva T, Vicente R, Rodrigues F, Samagaio A, Cardoso C. Development of a window shutter with phase change materials: Full scale outdoor experimental approach. Energy and Buildings 88 (2015), 110-121.

[38] Qahtan A, Keumala N, Rao SP, Abdul-Samad Z. Experimental determination of thermal performance of glazed façades with water film, under direct solar radiation in the tropics. Building and Environment 2011, 46, 2238-2246.

[39] Young $\mathrm{CH}$, Chen YL, Chen PC. Heat insulation solar glass and application on energy efficiency buildings. Energy and Buildings 2014, 78, 66-78.

[40] Manz H, Loutzenhiser PG, Frank T, Strachan PA, Bundi R and Maxwell GM. Series of experiments for empirical validation of solar gain modelling in building energy simulation codes - Experimental setup, test cell characterization, specifications and uncertainty analysis. Building and Environment 2006, 41, 1784-1797.

[41] Loutzenhiser PG, Manz H, Felsmann C, Strachan PA and Maxwell GM. An empirical validation of modelling solar gain through a glazing unit with external and internal shading screens. Applied Thermal Engineering 2007, 27, 528-538.

[42] Manz H, Schaelin A and Simmler H. Airflow patterns and thermal behavior of mechanically ventilated glass double façades. Building and Environment 2004, 39, 1023-1033.

[43] Loutzenhiser PG, Manz H, Moosberger S and Maxwell GM. An empirical validation of window solar gain models and the associated interactions. International Journal of Thermal Sciences $2009,48,85-95$.

[44] Kalyanova O and Heiselberg P. Empirical Validation of Building Simulation Software: Modelling of Double Facades: Final Report. Aalborg University, Dept. of Civil Engineering, Aalborg, Denmark, 2009.

[45] Kalyanova O, Heiselberg P, Felsmann C, Poirazis H, Strachan P and Wijsman A. An empirical validation of building simulation software for modelling of double-skin facade (DSF)

[46] Gavan V, Woloszyn M, Kuznik F, Roux J. Experimental study of a mechanically ventilated double-skin façade with venetian sun-shading device: A full-scale investigation in controlled environment. Solar Energy 2010, 84, 183-195.

[47] Kalema T and Haapala T. Effect of interior heat transfer coefficients on thermal dynamics and energy consumption. Energy and Buildings 1995, 22, 101-113.

[48] Bontemps S, Kaemmerlen A, Blatman G and Mora L. Reliability of dynamic simulation models for building energy in the context of low-energy buildings. Proceedings of 13th Conference of International Building Performance Simulation Association, Chambéry, France, August 26-28 2013. 
[49] Neymark J, Girault P, Guyon G, Judkoff R, LeBerre R, Ojalvo J and Reimer P. The "ETNA BESTEST" empirical validation data set. Ninth International IBPSA Conference, Montréal, Canada 2005.

[50] Doukas P. Final technical report - WP5: Research and Development Strategy, IQ-Test PASLINK EEIG, 2003.

[51] Mobile Window Thermal Test (MoWiTT) Facility http://windows.Ibl.gov/facilities/Mowitt/(last access on 27/01/2015)

[52] Klems JH. Net energy performance measurements on electrochromic skylights, Energy and Buildings 2001, 33, 93-102.

[53] Xu S, Liao W, Huang J, Kang J. Optimal PV cell coverage ratio for semi-transparent photovoltaics on office building façades in central China. Energy and Buildings 2014, 77, 130138.

[54] Janssens A, Hens H. Effects of wind on the transmission heat loss in duo-pitched insulated roofs: A field study. Energy and Buildings 2007, 39, 1047-1054.

[55] Guichard S, Miranville F, Bigot D and Boyer H. A thermal model for phase change materials in a building roof for a tropical and humid climate: Model description and elements of validation. Energy and Buildings 2014, 70, 71-80.

[56] Mara TA, Garde F, Boyer H and Mamode M. Empirical validation of the thermal model of a passive solar cell test. Energy and Buildings 2001, 33, 589-599.

[57] Miranville F, Boyer H, Mara T and Garde F. On the thermal behaviour of roof-mounted radiant barriers under tropical and humid climatic conditions: modelling and empirical validation. Energy and Buildings 2003, 35, 997-1008.

[58] Mateus NM, Pinto A and da Graça GC. Validation of EnergyPlus thermal simulation of a double skin naturally and mechanically ventilated test cell. Energy and Buildings 2014, 75, 511522.

[59] Stec WJ, van Paassen AHC. Symbiosis of the double skin façade with the HVAC system. Energy and Buildings 2005, 37, 461-469.

[60] Baker PH and McEvoy M. Test cell analysis of the use of a supply air window as a passive solar component. Solar Energy 2000, 69 (2), 113-130.

[61] Wouters $P$, Vandaele L, Voit P and Fisch N. The use of outdoor test cells for thermal and solar building research within the PASSYS project. Building and Environment 1993, 28, 107113.

[62] Dimoudi A, Androutsopoulos A and Lykoudis S. Experimental work on a linked, dynamic and ventilated, wall component. Energy and Buildings 2004, 36, 443-453.

[63] Contract JOU2-CT92-0221 - edited by Saxhof B. PASLINK calibration manual. Technical University of Denmark, 1995.

[64] Wouters P \& Vandaele L. The PASSYS services. Summary Report of the PASSYS Projects, Belgian Building Research Institute, EC DG XII, Brussels (1994).

[65] Van Dijk HAL and van der Linden GP. PASLINK Calibration and component test procedures. TNO, Delf, 1995.

[66] Goethals K, Delghust M, Flamant G, De Paepe M and Janssens A. Experimental investigation of the impact of room/system design on mixed convection heat transfer. Energy and Buildings 2012, 49, 542-551.

[67] Hahne E and Pfluger R. Improvements on PASSYS test cells. Solar Energy 1996, 58 (4-6), 239246.

[68] Maldonado E. COMPASS Upgrading PASSYS test cells with a Pseudo-adiabatic shell, construction manual. Universidade do Porto, JOULE2 Programme, Brussels, 1995. 
[69] García-Gáfaro C, Erkoreka A, Escudero-Revilla C, Flores I, Martínez-Fontecha J and Sala Lizarraga JM. Experience gained in the Thermal Characterization of Building Components by using PASLINK Test Cells. $5^{\text {th }}$ International Building Physics Conference (IBPC), Kyoto, 2012.

[70] Van Der Linden GP, Van Dijk HAL, Lock AJ and van der Graaf F. COMPASS Installation guide HFS Tiles for the PASSYS Test cells. TNO, JOULE2 Programme, Brussels, 1995.

[71] Pfluger R, Malzer H and Feist W. Testing of a Window Device with Integrated Shading and Ventilation System with PAS-Test Cell and Coldbox. DYNASTEE workshop on Dynamic Methods for Building Energy Assessment, 11 - 12 October 2010, Bruxelles.

[72] Van Dijk HAL and Tellez F. COMPASS Measurement and data analysis procedures. WTCBCSTC, Brussel, 1995.

[73] Erkoreka A. Modelling and testing of green roof using the PASLINK methodology for characterization of its energy behaviour. Ph.D. Thesis, Universidad del País Vasco, Bilbao 2012.

[74] Baker P. IQ-test-improving quality in testing and evaluation of solar and thermal characteristics of building components. Energy and Buildings 2004, 36, 435-441.

[75] http://dynastee.info/ (last access on 27/01/2015)

[76] Alcamo G. Daylight distribution and thermo-physical evaluation of new facade components through a test cell for the overheating control in Mediterranean Climate. $5^{\text {th }}$ International Conference SOLARIS, Czech Republic, 10-11 August 2011.

[77] Lopez TG and Molina CG. Influence of double glazing with a circulating water chamber on the thermal energy savings in buildings. Energy and Buildings 2013, 56, 56-65.

[78] Han J, Lu L, Peng J and Yang H. Performance of ventilated double-sided PV façade compared with conventional clear glass façade. Energy and Buildings 2013, 56, 204-209.

[79] Piccolo A. Thermal performance of an electrochromic smart window tested in an environmental test cell. Energy and Buildings 2010, 42, 1409-1417.

[80] Ahmad M, Bontemps A, Sallée H, Quenard D. Thermal testing and numerical simulation of a prototype cell using light wallboards coupling vacuum isolation panels and phase change material. Energy and Buildings 2006, 38, 673-681.

[81] Lodi C, Bacher P, Cipriano J and Madsen $\mathrm{H}$. Modelling the heat dynamics of a monitored Test Reference Environment for Building Integrated Photovoltaic systems using stochastic differential equations. Energy and Buildings 2012, 50, 273-281.

[82] Jimenez MJ, Roels S. Reliability of characterisation models and methods: A Round Robin Experiment on a test box. Seminar on Real building energy performance assessment, 16 April 2014 - Gent, Belgium.

[83] http://flexlab.lbl.gov/ (last access on 27/01/2015)

[84] http://www.dti.dk/projects/energyflexhouse (last access on 27/01/2015)

[85] Final report EUDP 2008 e II: CO2-reductions in low energy buildings and communities by implementation of low temperature district heating systems. Demonstration cases in Boligforeningen Ringgården and EnergyFlexHouse (partly in Danish), 2011, available at: http://www.byg.dtu.dk/Publikationer/Byg rapporter.aspx (last access on 27/01/2015)

[86] Causone F, Carlucci S, Pagliano L, Pietrobon M. A zero energy concept building for the Mediterranean climate, Energy Procedia 2014, 62, 280-288.

[87] Carlucci S, Cattarin G, Pagliano L, Pietrobon M. Optimization of the installation of an Earthto-Air Heat Exchanger and detailed design of a dedicated experimental set-up. Applied Mechanics and Materials 2014, 501-504, 2158-2161. 
[88] Carlucci S, Zangheri P, Pagliano L. Achieving the Net Zero Energy target in Northern Italy: lessons learned from an existing Passivhaus with Earth-to-Air Heat Exchanger. Advanced Materials Research 2013, 689, 184-187.

[89] Pisello AL, Cotana F, Nicolini A, Buratti C. Effect of dynamic characteristics of building envelope on thermal-energy performance in winter conditions: In field experiment. Energy and Buildings 2014, 80, 218-230.

[90] Gouy-Pailler C, Najmeddine H, Mouraud A, Suard F, Spitz C, Jay A, Maréchal P. Distance and similarity measures for sensors selection in heavily instrumented buildings: application to the INCAS platform. Proceedings of the CIB W78-W102 2011: International Conference -Sophia Antipolis, France, 26-28 October.

[91] http://www.arfrisol.es/ARFRISOLportal/ (last access on 27/01/2015)

[92] Vandaele L, Wouters $\mathrm{P}$, Bloem H. Hybrid photovoltaic building components: overall performance assessment by testing and simulation. Proceedings of the 14th European photovoltaic solar energy conference, Barcelona (1997), 1933-1936.

[93] Corgnati SP, Perino M and Serra V. Experimental assessment of the performance of an active transparent façade during actual operating conditions. Solar Energy 2007, 81, 993-1013.

[94] Flamant G, Lomcour X and Wouters P. Performance assessment of active façades in outdoor test cells. 23rd AIVC and EPIC 2002 Conference, Lyon, France, 23-26 October 2002.

[95] Flamant G, Prieus S, Loncour X, and L'heureux D. Ventilated double façades - Real-scale testing of ventilated double façades. Energy performance assessment. Belgian Building Research Institute (BBRI), 2004.

[96] Diarce G, Urresti A, García-Romero A, Delgado A, Erkoreka A, Escudero C, Campos-Celador A. Ventilated active façades with PCM. Applied Energy 109 (2013) 530-537.

[97] Goia F, Perino M, Serra V. Improving thermal comfort conditions by means of PCM glazing systems. Energy and Buildings 2013, 60, 442-452.

[98] Goia F, Perino M, Serra V. Experimental analysis of the energy performance of a full-scale PCM glazing prototype. Solar Energy 2014, 100, 217-233.

[99] De Gracia A, Navarro L, Castell A, Ruiz-Pardo A, Álvarez S, Cabeza LF. Thermal analysis of a ventilated facade with PCM for cooling applications. Energy and Buildings 2013, 65 508-515.

[100] Southall RG and McEvoy ME. Investigations into the functioning of a supply air window in relation to solar energy as determined by experiment and simulation. Solar Energy 2006, 80, 512-523.

[101] Heimonen I. Outdoor testing and analysis of the thermal performance of supply air window. Workshop on Dynamic Analysis Methods Applied to Energy Performance Assessment of Buildings. Warsaw 13-14 May 2004.

[102] Wei J, Zhao J and Chen Q. Energy performance of a dual airflow window under different climates. Energy and Buildings 2010, 42, 111-122.

[103] Simmler H \& Binder B. Experimental and numerical determination of the total solar energy transmittance of glazing with venetian blind shading. Building and Environment 2008, 43, 197204.

[104] Liu M, Wittchen KB, Heiselberg PK. Verification of a simplified method for intelligent glazed façade design under different control strategies in a full-scale façade test facility - Preliminary results of a south facing single zone experiment for a limited summer period. Building and Environment 2014, 82, 400-407.

[105] Saelens D, Roels S, and Hens H. The inlet temperature as a boundary condition for multipleskin facade modelling. Energy and Buildings 2004, 36, 825-835. 
[106] Carreras J, Boer D, Guillén-Gosálbez G, Cabeza LF, Medrano M, Jiménez L. Multi-objective optimization of thermal modelled cubicles considering the total cost and life cycle environmental impact. Energy and Buildings 2015, 88, 335-346.

[107] De Gracia A, Rincóna L, Castell A, Jiménez M, Boer D, Medrano M, Cabeza LF. Life Cycle Assessment of the inclusion of phase change materials (PCM) in experimental buildings. Energy and Buildings 2010, 42, 1517-1523.

[108] Menoufi K, Castell A, Farid MM, Boer D, Cabeza LF. Life Cycle Assessment of experimental cubicles including PCM manufactured from natural resources (esters): A theoretical study. Renewable Energy 2013, 51, 398-403.

[109] Caruana C, Grimab C, Yousifa C, Buhagiar S, Curmi R. Overview of testing methodologies for thermally improved hollow-core concrete blocks. Energy Procedia 2014, 62, 180-189.

[110] Pinard S, Fraisse G, Menezo C and Renzi V. Experimental study of a chimney enhanced heat emitter designed for internal renovation of buildings. Energy and Buildings 2012, 54, 169-178.

[111] Langmans J, Roels S. Experimental analysis of cavity ventilation behind rainscreen cladding systems: A comparison of four measuring techniques. Building and Environment 2015, 87, 177192.

[112] Janssens $A$ and Hens $H$. Effects of wind on the transmission heat loss in duo-pitched insulated roofs: A field study. Energy and Buildings 2007, 39, 1047-1054.

[113] Kotsiris G \& Androutsopoulos A. Testing the thermal performance of planted roofs by the use of Test Cells. DYNASTEE workshop on Dynamic Methods for Building Energy Assessment, 11 - 12 October 2010, Bruxelles.

[114] Rode C and Grau K. Whole building hygrothermal simulation model. ASHRAE Transactions, 2003, 572-582.

[115] Rode C and Grau SK. Integrated calculation of hygrothermal conditions of buildings. Proceedings of the 6th Symposium on Building Physics in the Nordic Countries. Vol. 1 Norwegian University of Science and Technology, 2002. p. 23-30.

[116] Abuku M, Blockend B and Roels S. Moisture response of building facades to wind-driven rain: Field measurements compared with numerical simulations. J. Wind Eng. Ind. Aerodyn. 2009, 97, 197-207.

[117] Zerihun Desta T, Langmans J and Roels S. Experimental data set for validation of heat, air and moisture transport models of building envelopes. Building and Environment 2011, 46(5), 1038-1046.

[118] Strachan PA. Simulation support for performance assessment of building components. Building and Environment 2008, 43, 228-236.

[119] Bloem J. Evaluation of a PV-integrated building application in a well-controlled outdoor test environment. Building and Environment 2008, 43, 205-216.

[120] Argiriou A, Bellas-Velidis I and Balaras CA. Development of a neural network heating controller for solar buildings. Neural Networks 2000, 13, 811-820.

[121] Neymark J, Judkoff R, Knabec G, Lec H-T, Dürig M, Glasse A and Zweifele G. Applying the building energy simulation test (BESTEST) diagnostic method to verification of space conditioning equipment models used in whole-building energy simulation programs. Energy and Buildings 2002, 34, 917-931.

[122] Jensen SO. Validation of building energy simulation programs: a methodology. Energy and Buildings 1995, 22, 133-144. 
[123] Judkoff R, Wortman D and Burch J. Empirical Validation of Building Analysis Simulation Programs: A Status Report. Solar Energy Research Institute, Colorado, 1982.

[124] Judkoff R, Wortman D, O'Doherty B and Burch J. Methodology for Validating Building Energy Analysis Simulations. National Renewable Energy Laboratory, United States, 2008.

[125] Jensen, S. Empirical Whole Model Validation Case Study: the PASSYS Reference Wall. Proceedings of Building Simulation 1993, Adelaide, Australia.

[126] ANSI/ASHRAE, Standard 140-2007-Standard Method of Test for the Evaluation of Building Energy Analysis Computer Programs. ANSI/ASHRAE, Atlanta, 2007.

[127] Loutzenhiser PG, Maxwell GM and Manz H. An empirical validation of the daylighting algorithms and associated interactions in building energy simulation programs using various shading devices and windows. Energy 2007, 32, 1855-1870.

[128] Neymark J and Judkoff R. Diagnostic Method for Heating, Ventilating, and Air-Conditioning Equipment Models (HVAC BESTEST). 2002 Technical Report IEA - Solar Heating and Cooling Programme.

[129] Bakker EJ. Ecobuild research: full-scale testing of innovative technologies for energy efficient houses. DAME-BC Conference, 2003, Ispra, Italy.

[130] Mills AF and Chang BH. Error analysis of experiments - A manual for engineering students. University of California, Los Angeles, California, 2004.

[131] Judkoff R and Neymark J. Model Validation and Testing: the Methodological Foundation of ASHRAE Standard 140. ASHRAE 2006 Annual Meeting, Quebec City, Canada.

[132] Moinard S \& Guyon G. Empirical validation of EDF ETNA and GENEC test-cell models, A Report of Task 22, Subtask A.3 Empirical Validation, International Energy Agency 1999.

[133] Clarke J A, Strachan P and Pernot C. An Approach to the Calibration of Building Energy Simulation Models. ASHRAE Transactions 1993, 99(2), 917-927.

[134] Park C, Augenbroe G, Messadi T, Thitisawat M and Sadegh N. Calibration of a lumped simulation model for double-skin façade systems. Energy and Buildings 2004, 36 (11), 11171130.

[135] Ryan EM and Sanquist TF. Validation of building energy modeling tools under idealized and realistic conditions, Energy and Buildings 2012, 47, 375-382.

[136] Wouters P \& Vandaele L. Towards a standard for outdoor thermal testing: barriers to overcome. Workshop on "Quality assurance in Testing, Analysis and Modeling", JRC - Ispra, 1996.

[137] Frank T and Binder B. Modelling of outdoor boundary conditions - analysis of field measurements on windows. International Conference "Dynamic Analysis and Modelling Techniques", Ispra 13-14 November 2003.

[138] CEN TC89 WG13: In-situ thermal performance of construction products, building elements and structures. See web page: http://standards.cen.eu/dyn/www/f?p=CENWEB:7:0::::FSP ORG ID:735956\&cs=18261A6A2D A99F51E6D12F572C2C6AD19 (last access on 27/01/2015)

[139] Flamant G. Standardisation of methods for in-situ performance assessment. Seminar on Real building energy performance assessment, 16 April 2014 - Gent, Belgium.

[140] Baker PH and van Dijk HAL. PASLINK and dynamic outdoor testing of building components. Building and Environment 2008, 43, 143-151.

[141] ISO 9869:1994(E). Thermal insulation - Building components and elements - in-situ measurement of the thermal resistance and thermal transmittance, 1994. 
[142] Janssens A, Alcamo G, Bacher P, Erkoreka A, Flamant G, Himpe E. State of the art on test facilities and data analysis methods. Seminar on Real building energy performance assessment, 16 April 2014 - Gent, Belgium.

[143] Bloem J. Evaluation of the System Identification Competition. Workshop on "Quality assurance in Testing, Analysis and Modeling", JRC - Ispra, 1996.

[144] Baker P, Bloem H, van Dijk D, Gutschker O and Jiménez MJ. System Identification Methods applied for the assessment of thermal parameters of building components. International Conference on Dynamic Analysis and Modelling Techniques, 2003. ISBN 92-894-7794-6.

[145] Gutschker O. Parameter identification under difficult conditions - how much information is contained in the objective function? Conference proceeding from "Dynamic Analysis, Simulation and Testing applied to the Energy and Environmental Performance of Buildings", 12-14 October 2005, Athens.

[146] Belok J. Determination of $U$ and $g$ coefficient for external partitions with transparent insulation using "LORD" software. Conference proceeding from "Dynamic Analysis, Simulation and Testing applied to the Energy and Environmental Performance of Buildings", 12-14 October 2005, Athens.

[147] Jimenez MJ, Madsen $\mathrm{H}$, Andersen KK. Identification of the main thermal characteristics of building components using MATLAB. Building and Environment 2008, 43, 170-180.

[148] Jiménez MJ and Madsen $\mathrm{H}$. Models for describing the thermal characteristics of building components. Building and Environment 2008, 43 (2), 152-162.

[149] Madsen H. Time series analysis. Chapman \& Hall, 380 pages, 2008 ISBN-10: 142005967X | ISBN-13: 978-14200596700

[150] Bloem JJ. System identification applied to building performance data. Joint Research Centre, European Commission, 1994 - 306 pages.

[151] Menezo C, Dupeyrat P and Haurant P. Innovative design, construction and performance of hybrid photovoltaic-thermal collectors. Workshop on Potential Technological Developments for Zero carbon Buildings. Hong-Kong 2013 - October 16-17

[152] Hens $H$, Janssens $A$ and Zheng R. Zinc roofs: an evaluation based on test house measurements. Building and Environment 2003, 38, 795-806.

[153] Roels $S$ and Deurinck M. The effect of a reflective underlay on the global thermal behaviour of pitched roofs. Building and Environment 2011, 46, 134-143. 